\title{
Needle age-related and seasonal photosynthetic capacity variation is negligible for modelling yearly gas exchange of a sparse temperate Scots pine forest
}

\author{
M. Op de Beeck ${ }^{1, *}$, B. Gielen ${ }^{1, *}$, I. Jonckheere ${ }^{2}$, R. Samson ${ }^{3}$, I. A. Janssens ${ }^{1}$, and R. Ceulemans ${ }^{1}$ \\ ${ }^{1}$ Research Group of Plant and Vegetation Ecology, Department of Biology, University of Antwerp, Wilrijk, Belgium \\ ${ }^{2}$ Biosystems Department, Geomatics Group, Katholieke Universiteit Leuven, Leuven, Belgium \\ ${ }^{3}$ Department of Bioscience Engineering, University of Antwerp, Antwerpen, Belgium \\ *these authors contributed equally to this manuscript
}

Received: 22 September 2009 - Published in Biogeosciences Discuss.: 9 October 2009

Revised: 15 December 2009 - Accepted: 18 December 2009 - Published: 14 January 2010

\begin{abstract}
In this study, we quantified the predictive accuracy loss involved with omitting photosynthetic capacity variation for a Scots pine (Pinus sylvestris L.) stand in Flanders, Belgium. Over the course of one phenological year, we measured the maximum carboxylation capacity at $25^{\circ} \mathrm{C}\left(V_{\mathrm{m} 25}\right)$, the maximum electron transport capacity at $25^{\circ} \mathrm{C}\left(J_{\mathrm{m} 25}\right)$, and the leaf area index (LAI) of different-aged needle cohorts in the upper and lower canopy. We used these measurements as input for a process-based multi-layer canopy model with the objective to quantify the difference in yearly gross ecosystem productivity (GEP) and canopy transpiration $\left(E_{\text {can }}\right)$ simulated under scenarios in which the observed needle age-related and/or seasonal variation of $V_{\mathrm{m} 25}$ and $J_{\mathrm{m} 25}$ was omitted. We compared simulated GEP with estimations obtained from eddy covariance measurements. Additionally, we measured summer needle $\mathrm{N}$ content to investigate the relationship between photosynthetic capacity parameters and needle $\mathrm{N}$ content along different needle ages.

Results show that $V_{\mathrm{m} 25}$ and $J_{\mathrm{m} 25}$ were, respectively, 27\% and $13 \%$ higher in current-year than in one-year old needles. A significant seasonality effect was found on $V_{\mathrm{m} 25}$, but not on $J_{\mathrm{m} 25}$. Summer needle $\mathrm{N}$ content was considerably lower in current-year than in one-year-old needles. As a result, the correlations between $V_{\mathrm{m} 25}$ and needle $\mathrm{N}$ content and $J_{\mathrm{m} 25}$ and needle $\mathrm{N}$ content were negative and non-significant, respectively. Some explanations for these unexpected correlations were brought forward. Yearly GEP was overestimated
\end{abstract}

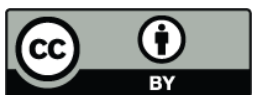

Correspondence to: M. Op de Beeck (maarten.opdebeeck@ua.ac.be) by the canopy model by $\pm 15 \%$ under all scenarios. The inclusion and omission of the observed needle age-related $V_{\mathrm{m} 25}$ and $J_{\mathrm{m} 25}$ variation in the model simulations led to statistically significant but ecologically irrelevant differences in simulated yearly GEP and $E_{\text {can }}$. Omitting seasonal variation did not yield significant simulation differences. Our results indicate that intensive photosynthetic capacity measurements over the full growing season and separate simulation of needle age classes were no prerequisites for accurate simulations of yearly canopy gas exchange. This is true, at least, for the studied stand, which has a very sparse canopy and is exposed to high $\mathrm{N}$ deposition and, hence, is not fully representative for temperate Scots pine stands. Nevertheless, we believe well-parameterized process-based canopy models as applied in this study - are a useful tool to quantify losses of predictive accuracy involved with canopy simplification in modelling.

\section{Introduction}

Coniferous canopies have a complex heterogeneous structure, both in terms of foliage architecture and physiology. For example, needles are unevenly distributed in the canopy through aggregation into whorls, clumps and cohorts (e.g., Čermák et al., 1998), while needle physiological properties vary with canopy position (Peters et al., 2008), needle age (Wang et al., 1995), and time of growing season (Misson et al., 2006). Reliable estimates of conifer canopy gas exchange therefore require an accurate characterization of the canopy structure in space and time (Monteith, 1975; Stenberg et al.,

Published by Copernicus Publications on behalf of the European Geosciences Union. 
1994). In process-based multi-layer canopy models this condition is typically met as their framework allows for a detailed description of foliage distribution, physiological gradients, and radiation transfer within the canopy. Moreover, they often include photosynthetic capacity and leaf area changes related to needle age (e.g., Mohren and van de Veen, 1995; Tingey et al., 2001; Weiskittel, 2006) and time in the growing season (e.g., Ogée et al., 2003). Due to the large input parameter requirement and number of calculations involved, it is not feasible to represent canopy complexity in such detail in models simulating canopy gas exchange at the larger scale such as land surface schemes used in general circulation models (e.g., Verseghy, 2000; Kowalczyk et al., 2006). In those models, the canopy scheme is reduced to one sun/shade layer and needle age-related and seasonal photosynthetic capacity variation is mostly not taken into account. Whereas the use of one/shade layer and the spatial averaging of photosynthetic capacity has been shown not to induce significant accuracy loss (de Pury and Farquhar, 1997; Wang and Leuning, 1998), the omittance of needle age-related and seasonal photosynthetic capacity variation could lead to considerably less accurate estimations of conifer canopy gas exchange (Ogée et al., 2003; also: Wilson et al., 2001 for a deciduous canopy).

Additionally, the general relationship between photosynthetic capacity and needle nitrogen $(\mathrm{N})$ content (Field and Mooney, 1986) is not clear along different needle ages in conifers (Vapaavuori et al., 1995; Warren et al., 2003), though leaf $\mathrm{N}$ content is commonly used as an indicator for photosynthetic capacity because of its close association with the amounts of photosynthesis-related $\mathrm{N}$ compounds such as chlorophyll and Rubisco (Evans, 1989).

In this study, we quantified the predictive accuracy loss involved with omitting photosynthetic capacity variation for a Scots pine (Pinus sylvestris L.) stand in Flanders, Belgium. Over the course of one phenological year, we measured the photosynthetic capacity parameters maximum carboxylation capacity at $25^{\circ} \mathrm{C}\left(V_{\mathrm{m} 25}\right)$ and maximum electron transport capacity at $25^{\circ} \mathrm{C}\left(J_{\mathrm{m} 25}\right)$ and the leaf area index (LAI) of different-aged needles in the upper and lower canopy. We used these measurements as input for a process-based multilayer canopy model with the objective to quantify the difference in yearly gross ecosystem productivity (GEP) and canopy transpiration $\left(E_{\mathrm{can}}\right)$ simulated under scenarios in which the observed needle age-related and/or seasonal variation of $V_{\mathrm{m} 25}$ and $J_{\mathrm{m} 25}$ was omitted. We compared simulated GEP with estimations obtained from eddy covariance measurements. Additionally, we measured summer needle $\mathrm{N}$ content to investigate the relationship between photosynthetic capacity parameters and needle $\mathrm{N}$ content along different needle ages.

\section{Materials and methods}

\subsection{Experimental site}

The experimental site is an even-aged, 2 ha Scots pine stand, representing a portion of the 150 ha mixed coniferous/deciduous De Inslag forest. The forest is located in Brasschaat, in the Campine region of the province of Antwerpen, Belgium $\left(51^{\circ} 18^{\prime} 33^{\prime \prime} \mathrm{N}, 4^{\circ} 31^{\prime} 14^{\prime \prime} \mathrm{E}\right.$, altitude, $16 \mathrm{~m}$ a.s.l.). The stand was a level II observation plot of the European program for intensive monitoring of forest ecosystems (EC regulation No. 3528/86), managed by the Flemish Research Institute for Nature and Forestry (Flanders, Belgium). Ten-year mean annual and growing season (AprilOctober) temperature at the site are 11.8 and $14.9^{\circ} \mathrm{C}$, respectively. Mean annual and growing season precipitation are 824 and $505 \mathrm{~mm}$, respectively. Rainfall is fairly evenly distributed throughout the year. The study site has a flat topography (slope less than 0.3\%). The upper soil layer is ca. $1.8 \mathrm{~m}$ thick. The soil has been described as a moderately wet sandy soil with a distinct humus and/or iron B-horizon (Baeyens et al., 1993). Due to a clay layer at a depth of 1.5 to $2 \mathrm{~m}$ the site has poor drainage. The soil is moist and often saturated, with a high hydraulic conductivity in the upper soil layer.

The Scots pine stand was planted in 1929 and was 78 years old at the time of the present study (2007-2008). The present stock density is 374 trees ha $^{-1}$ (Xiao et al., 2003). Average diameter at breast height is $0.3 \mathrm{~m}$ and average tree height is $21.4 \mathrm{~m}$. The stand canopy is sparse, with a peak projected LAI of $1.31 \mathrm{~m}^{2} \mathrm{~m}^{-2}$ in 2007 (this study) and a mean canopy gap fraction of $42 \%$. The canopy has a mean depth of $8.3 \mathrm{~m}$ (Xiao et al., 2003). The pine trees only bear two needle age classes (current-year needles and one-year-old needles), as nearly all needles older than two years are dropped in winter (Janssens et al., 1999). Needle analysis has shown the stand to be low in magnesium and phosphorus (Van den Berge et al., 1992; Roskams et al., 1997). However, needle N content was optimal ( $>2 \%$ in current-year needles; Roskams and Neirynck, 1999), most probably because the pine stand is located in an area with high $\mathrm{NO}_{\mathrm{x}}$ and ammonia deposition (30$40 \mathrm{~kg} \mathrm{ha}^{-1} \mathrm{y}^{-1}$; Neirynck et al., 2005, 2007), with high $\mathrm{NO}_{3}^{-}$ leaching to the ground water (Neirynck et al., 2008).

\subsection{Photosynthetic parameter measurements and needle $\mathrm{N}$ analysis}

The photosynthetic parameters $V_{\mathrm{m} 25}$ and $J_{\mathrm{m} 25}$ were derived from in situ gas exchange measurements. Platforms on a $41 \mathrm{~m}$ high flux tower positioned in the middle of the stand gave access to the crown of two pine trees growing near the tower. Gas exchange was measured on attached current-year and one-year-old needles in the upper and lower crown of these two pines with a portable open-path gas exchange measurement system (LI-6400, Li-COR, Lincoln, NE, USA). 
Measurements were carried out at five dates in the phenological year 1 May 2007-30 April 2008, on a monthly basis (June, July, August, and September 2007; April 2008). At each sampling, within the first week of the month, between 15 and 30 needle samples (each 6 to 8 needles, i.e. 3 to 4 fascicles) were placed into the LI-6400 leaf chamber. Foam mounting paths held the needles in the chamber, preventing self-shading. Response curves of needle photosynthesis to $\mathrm{CO}_{2}\left(A_{\mathrm{n}} / C_{\mathrm{i}}\right)$ were generated at $25^{\circ} \mathrm{C}$ under saturating conditions of photosynthetically active radiation (PAR; $1000 \mu \mathrm{mol} \mathrm{m}^{-2} \mathrm{~s}^{-1}$ ). Photosynthetic responses were measured at ten $\mathrm{CO}_{2}$ concentrations, in the following order: $360,180,100,70,45,360,560,720,1000$, and $2000 \mathrm{ppm}$. In a number of cases, leaf respiration rate at $25^{\circ} \mathrm{C}\left(R_{\mathrm{d} 25}\right)$ was measured at PAR $=0 \mu \mathrm{mol} \mathrm{m}^{-2} \mathrm{~s}^{-1}$, prior to the $A_{\mathrm{n}} / C_{\mathrm{i}}$ curve assessment. During measurements leaf chamber humidity varied between 50 and $80 \%$. Values for the photosynthetic parameters $V_{\mathrm{m} 25}$ and $J_{\mathrm{m} 25}$ were derived from the $A_{\mathrm{n}} / C_{\mathrm{i}}$ curves by fitting the biochemical photosynthesis model of Farquhar (Farquhar et al., 1980) with the least squares method.

After gas exchange measurements, needles were harvested and projected needle area was estimated using a binocular microscope (M5 Wild, Wild Heerbrugg, Gais, Switzerland) in combination with an ocular equipped with a reticule (Leitz, Wetzlar, Germany, periplan, GW 10xm). Needles sampled in June, July, and August 2007 were subsequently dried in a dry oven $\left(70^{\circ} \mathrm{C}, 72 \mathrm{~h}\right)$. After grounding in a mill (Cyclotech 1093, Sample Mill, Sweden), they were analyzed for $\mathrm{N}$ by a dynamic Flush Combustion Method with a NC 2100 Soil Analyzer (Carlo Erba Strumentazione, Rodano, Italy). From biomass-based needle $\mathrm{N}$ content $\left(N_{\mathrm{b}}\right)$ and projected needle area, area-based needle $\mathrm{N}$ content $\left(N_{\mathrm{a}}\right)$ was calculated. A list of all symbols and notations used in this study is given in Table 1 .

\subsection{Leaf area index measurements}

Effective LAI was determined by an optical close-range remote sensing method, using hemispherical canopy photographs as described by Jonckheere et al. (2005a, b). The photographs were taken at 30 points in a systematic sampling grid within the experimental plot at a biweekly interval from 28 March 2007 till 31 January 2008. Effective LAI measures were calculated from binarized photographs resulting from an automatic global thresholding algorithm combined with a local thresholding algorithm in order to correct for local light anomalies (e.g., sun flecks, underexposure) in the photographs (Jonckheere et al., 2005b, 2006). Post correction for clumping on branch- and tree-level was done by dividing the measured effective LAI by a clumping factor for Scots pine (0.83) (Jonckheere et al., 2005a). Daily values were obtained through linear interpolation. The LAI pattern for the different age classes was reconstructed using litter fall data. Litter fall was measured at a biweekly interval between May
2007 and December 2007 on 10 places within the experimental plot with litter collectors (surface area of $0.3 \mathrm{~m}^{2}$ ) made from nylon-mesh netting. All litter was oven-dried $(48 \mathrm{~h}$, $75^{\circ} \mathrm{C}$ ), sorted into branches, needles and reproductive organs, and weighed. Current-year needle LAI was calculated as the sum of needle litter fall and the increase of total LAI until it reached a maximum (early September 2007). Oneyear-old needle LAI was calculated as the difference between total and current-year needle LAI. A relative distribution of current-year and one-year-old needle LAI between the upper and lower canopy was estimated from destructive sampling in August 2007. This was done by measuring currentyear and one-year-old needle dry weight for four harvested branches from the upper and lower crown of five trees surrounding the flux tower. These dry weight values were averaged and converted to LAI values by multiplication with specific leaf area values from a previous site study (Xiao et al., 2006).

\subsection{Gross ecosystem productivity measurements}

Gross ecosystem productivity (GEP) was estimated from vertical $\mathrm{CO}_{2}$ flux measurements above the canopy using the eddy covariance technique (Baldocchi and Meyers, 1998). The measurements were conducted at the top of the tower at a height of $41 \mathrm{~m}$, circa $18 \mathrm{~m}$ above the canopy. The eddy covariance system consisted of a sonic anemometer (Model SOLENT 1012R2, Gill Instruments, Lymington, UK) for wind speed and an infrared gas analyser (IRGA) (Model LI6262, LI-COR Inc., Lincoln, NE, USA) to measure the $\mathrm{CO}_{2}$ concentrations. A detailed description of the experimental setup can be found in Kowalski et al. (2000) and Carrara et al. (2003). Half-hourly net ecosystem exchange fluxes were calculated following the recommendations of the Euroflux network (Aubinet et al., 2000; Reichstein et al., 2005; Papale et al., 2006). Gap-filling and separation of net ecosystem exchange fluxes into total ecosystem respiration and GEP was done as described by Reichstein et al. (2005).

\subsection{Meteorology}

On top of the flux tower, $41 \mathrm{~m}$ above ground level, the following meteorological variables were measured at $0.1 \mathrm{~Hz}$ : incoming solar irradiance (I) (Kipp and Zonen CM6B, the Netherlands), air temperature $(T)$ and relative humidity (RH) (DTS-5A, Didcot Instrument Co Ltd, Abingdon, United Kingdom), atmospheric pressure $\left(p_{\mathrm{a}}\right)$ (SETRA Barometric Pressure transducer Model 278, Setra systems, Boxborough, MA, USA), and wind speed ( $v$ ) (Didcot DWR-205G). Measurement data were converted to half-hourly means and stored on a data logger (Campbell CR10, United Kingdom). Data gaps were filled with data from nearby weather stations. Air vapour pressure deficit (VPD) was derived from measured RH and $T$, following Jones (1992). Half-hourly atmospheric $\mathrm{CO}_{2}$ concentration $\left(C_{\mathrm{a}}\right)$ was obtained by averaging 
Table 1. List of symbols and notations used in this study, with their units and definition.

\begin{tabular}{|c|c|c|}
\hline symbol & units & definition \\
\hline$a_{1}$ & dimensionless & empirical scaling parameter \\
\hline$A_{\mathrm{b}}$ & $\mu \mathrm{mol} \mathrm{m}{ }^{-2} \mathrm{~s}^{-1}$ & gross photosynthesis \\
\hline$A_{\mathrm{bsun}(i, j)}$ & $\mu \mathrm{mol} \mathrm{m}{ }^{-2} \mathrm{~s}^{-1}$ & gross photosynthesis of $j$-aged needles in the sunlit fraction of a canopy layer $i$ \\
\hline$A_{\text {bshad }(i, j)}$ & $\mu \mathrm{mol} \mathrm{m}{ }^{-2} \mathrm{~s}^{-1}$ & gross photosynthesis of $j$-aged needles in the shaded fraction of a canopy layer $i$ \\
\hline$A_{\mathrm{n}}$ & $\mu \mathrm{mol} \mathrm{m}{ }^{-2} \mathrm{~s}^{-1}$ & nitrogen-limited gross photosynthesis \\
\hline$A_{\mathrm{j}}$ & $\mu \mathrm{mol} \mathrm{m}{ }^{-2} \mathrm{~s}^{-1}$ & light-limited gross photosynthesis \\
\hline$A_{\mathrm{V}}$ & $\mu \mathrm{mol} \mathrm{m}{ }^{-2} \mathrm{~s}^{-1}$ & net photosynthesis \\
\hline$C_{\mathrm{a}}$ & ppm & atmospheric $\mathrm{CO}_{2}$ concentration \\
\hline$C_{\mathrm{S}}$ & ppm & leaf surface $\mathrm{CO}_{2}$ concentration \\
\hline$C_{\mathrm{i}}$ & ppm & leaf intercellular $\mathrm{CO}_{2}$ concentration \\
\hline$d$ & $\mathrm{~m}$ & characteristic needle dimension (=needle diameter) \\
\hline$E$ & $\mathrm{~mol} \mathrm{~m}^{-2} \mathrm{~s}^{-1}$ & transpiration rate \\
\hline$E_{\mathrm{aVm}}$ & $\mathrm{J} \mathrm{mol}^{-1}$ & activation energy for $V_{\mathrm{m}}$ \\
\hline$E_{\mathrm{aJm}}$ & $\mathrm{J} \mathrm{mol}^{-1}$ & activation energy for $J_{\mathrm{m}}$ \\
\hline$E_{\mathrm{aRd}}$ & $\mathrm{J} \mathrm{mol}^{-1}$ & activation energy for $R_{\mathrm{d}}$ \\
\hline$E_{\mathrm{aKo}}$ & $\mathrm{J} \mathrm{mol}^{-1}$ & activation energy for $K_{\mathrm{O}}$ \\
\hline$E_{\mathrm{aKc}}$ & $\mathrm{J} \mathrm{mol}^{-1}$ & activation energy for $K_{\mathrm{c}}$ \\
\hline$E_{\text {can }}$ & $\mathrm{g} \mathrm{H}_{2} \mathrm{O} \mathrm{m} \mathrm{m}^{-2} \mathrm{~s}^{-1}$ & instant canopy transpiration \\
\hline & $\mathrm{g} \mathrm{H}_{2} \mathrm{O} \mathrm{m}^{-2} \mathrm{~d}^{-1}$ & daily canopy transpiration \\
\hline & $\mathrm{kg} \mathrm{H}_{2} \mathrm{O} \mathrm{m}^{-2} \mathrm{y}^{-1}$ & yearly canopy transpiration \\
\hline$f$ & dimensionless & spectral correction factor \\
\hline$f_{\operatorname{sun}(i)}$ & dimensionless & sunlit LAI fraction of a canopy layer $i$ \\
\hline$f_{\text {shad }(i)}$ & dimensionless & shaded LAI fraction of a canopy layer $i$ \\
\hline$f_{\mathrm{VPD}}$ & dimensionless & VPD-function, ranging between 0 and 1 \\
\hline$g_{\text {st }}$ & $\mathrm{mol} \mathrm{m}^{-2} \mathrm{~s}^{-1}$ & stomatal conductance to $\mathrm{CO}_{2}$ \\
\hline$g_{0}$ & $\mathrm{~mol} \mathrm{~m}^{-2} \mathrm{~s}^{-1}$ & night-time conductance to $\mathrm{CO}_{2}$ \\
\hline$g_{\text {tot }}$ & $\mathrm{mol} \mathrm{m}^{-2} \mathrm{~s}^{-1}$ & total leaf conductance to $\mathrm{CO}_{2}$ \\
\hline$g_{\mathrm{bl}}$ & $\mathrm{mol} \mathrm{m}^{-2} \mathrm{~s}^{-1}$ & leaf boundary layer conductance to $\mathrm{CO}_{2}$ \\
\hline GEP & $\mathrm{g} \mathrm{C} \mathrm{m}^{-2} \mathrm{~s}^{-1}$ & instant gross ecosystem productivity \\
\hline & $\mathrm{g} \mathrm{C} \mathrm{m}^{-2} \mathrm{~d}^{-1}$ & daily gross ecosystem productivity \\
\hline & $\mathrm{kg} \mathrm{C} \mathrm{m}^{-2} \mathrm{y}^{-1}$ & yearly gross ecosystem productivity \\
\hline$H$ & $\mathrm{~J} \mathrm{~mol}^{-1}$ & curvature parameter of $J_{\mathrm{m}}$ \\
\hline$I$ & $\mathrm{~W} \mathrm{~m}^{-2}$ & incoming solar irradiance \\
\hline$I_{\mathrm{b} 0}$ & $\mathrm{~W} \mathrm{~m}^{-2}$ & direct beam irradiance at the canopy top \\
\hline$I_{\mathrm{d} 0}$ & $\mathrm{~W} \mathrm{~m} \mathrm{~m}^{-2}$ & diffuse irradiance at the canopy top \\
\hline$I_{\mathrm{d}(i)}$ & $\mathrm{W} \mathrm{m}^{-2}$ & diffuse irradiance in a canopy layeri \\
\hline$I_{\mathrm{sun}(i)}$ & $\mathrm{W} \mathrm{m}^{-2}$ & total received irradiance by the sunlit fraction of a canopy layer $i$ \\
\hline$I_{\text {shad }(i)}$ & $\mathrm{W} \mathrm{m}^{-2}$ & total received irradiance by the shaded fraction of a canopy layer $i$ \\
\hline$J$ & $\mu \mathrm{mol} \mathrm{m}{ }^{-2} \mathrm{~s}^{-1}$ & actual electron transport rate per unit leaf area \\
\hline$J_{\mathrm{m}}, J_{\mathrm{m} 25}$ & $\mu \mathrm{mol} \mathrm{m}{ }^{-2} \mathrm{~s}^{-1}$ & maximum electron transport rate per unit leaf area, at prevailing temperature and at $25^{\circ} \mathrm{C}$ \\
\hline & ppm & beam radiation extinction coefficient \\
\hline$k_{\mathrm{d}}$ & $\mathrm{ppm}$ & diffuse radiation extinction coefficient \\
\hline$K_{\mathrm{c}}, K_{\mathrm{c} 25}$ & ppm & Michaelis-Menten constant of Rubisco for $\mathrm{CO}_{2}$, at prevailing temperature and at $25^{\circ} \mathrm{C}$ \\
\hline$K_{\mathrm{O}}, K_{\mathrm{o} 25}$ & ppm & Michaelis-Menten constant of Rubisco for $\mathrm{O}_{2}$, at prevailing temperature and at $25^{\circ} \mathrm{C}$ \\
\hline LAI & $\mathrm{m}^{2} \mathrm{~m}^{-2}$ & leaf area index \\
\hline $\mathrm{LAI}_{\mathrm{c}(i)}$ & $\mathrm{m}^{2} \mathrm{~m}^{-2}$ & cumulative leaf area index above a canopy layer $i$, from the canopy top \\
\hline $\mathrm{LAI}_{\text {sun }}(i, j)$ & $\mathrm{m}^{2} \mathrm{~m}^{-2}$ & leaf area index of $j$-aged needles in the sunlit and shaded fraction of a canopy layer $i$ \\
\hline $\mathrm{LAI}_{\text {shad }(i, j)}$ & $\mathrm{m}^{2} \mathrm{~m}^{-2}$ & leaf area index of $j$-aged needles in the sunlit and shaded fraction of a canopy layer $i$ \\
\hline$N_{\mathrm{b}}$ & $\mathrm{g} \mathrm{g}^{-1} \mathrm{DW}$ & biomass-based needle $\mathrm{N}$ content \\
\hline$N_{\mathrm{a}}$ & $\mathrm{mmol} \mathrm{m}^{-2}$ & area-based needle $\mathrm{N}$ content \\
\hline$O$ & ppm & leaf intercellular $\mathrm{O}_{2}$ concentration \\
\hline$p_{\mathrm{a}}$ & $\mathrm{kPa}$ & atmospheric pressure \\
\hline PAR & $\mu \mathrm{mol} \mathrm{m}{ }^{-2} \mathrm{~s}^{-1}$ & photosynthetically active radiation \\
\hline PAR $_{\text {PSII }}$ & $\mu \mathrm{mol} \mathrm{m}{ }^{-2} \mathrm{~s}^{-1}$ & photosynthetically active radiation effectively absorbed by photosystem II \\
\hline$R$ & $\mathrm{~J} \mathrm{~mol}^{-1} \mathrm{~K}^{-1}$ & universal gas constant \\
\hline$R_{\mathrm{d}}, R_{\mathrm{d} 25}$ & $\mu \mathrm{mol} \mathrm{m}{ }^{-2} \mathrm{~s}^{-1}$ & leaf respiration rate per unit leaf area, at prevailing temperature and at $25^{\circ} \mathrm{C}$ \\
\hline$R_{\mathrm{d} 25} / V_{\mathrm{m} 25}$ & dimensionless & ratio of leaf respiration rate to maximum carboxylation rate under RuBP saturation at $25^{\circ} \mathrm{C}$ \\
\hline $\mathrm{RH}$ & $\%$ & relative humidity \\
\hline$S$ & $\mathrm{~J} \mathrm{~mol}^{-1} \mathrm{~K}^{-1}$ & electron-transport temperature response parameter \\
\hline
\end{tabular}


Table 1. Continued.

\begin{tabular}{lll}
\hline symbol & units & definition \\
\hline$T$ & ${ }^{\circ} \mathrm{C}$ & air temperature \\
$v$ & $\mathrm{~m} \mathrm{~s}^{-1}$ & wind speed \\
$V_{\mathrm{m}}, V_{\mathrm{m} 25}$ & $\mu \mathrm{mol} \mathrm{m} \mathrm{s}^{-2} \mathrm{~s}^{-1}$ & maximum carboxylation rate per unit leaf area under RuBP saturation, at prevailing temperature and at $25^{\circ} \mathrm{C}$ \\
$\mathrm{VPD}$ & $\mathrm{kPa}$ & air vapour pressure deficit \\
$\mathrm{VPD} 0$ & $\mathrm{kPa}$ & empirical parameter \\
$\alpha_{\mathrm{PAR}}$ & dimensionless & needle PAR absorptivity \\
$\beta$ & $\circ$ & solar elevation angle \\
$\Gamma$ & $\mathrm{ppm}$ & $\mathrm{CO}_{2}$ compensation point \\
$\Gamma^{\prime}, \Gamma^{\prime} 25$ & ppm & $\mathrm{CO}_{2}$ compensation point in the absence of mitochondrial respiration, at prevailing temperature and at $25^{\circ} \mathrm{C}$ \\
$\theta$ & dimensionless & curvature of leaf response of electron transport to PAR \\
$\Omega$ & dimensionless & factor accounting for inter- and intra-crown foliage clumping \\
\hline
\end{tabular}

$20.8 \mathrm{~Hz}$ measurements that were conducted on top of the tower with an Infra Red Gas Analyser (IRGA) (Model LI6262, LI-COR Inc., Lincoln, NE, USA). These meteorological data were used as input for the canopy model. Precipitation was measured with a rain gauge (Didcot DRG-51) and recorded half-hourly.

\subsection{Canopy model: description}

The process-based multi-layer canopy model applied in this study is a generic model and is described in detail in Appendix A. The model includes a radiation submodel (Goudriaan, 1977) and a leaf physiological submodel (Farquhar et al., 1980; Leuning, 1995). It simulates gross ecosystem productivity (GEP) and canopy transpiration $\left(E_{\text {can }}\right)$ on a halfhourly time resolution. It is driven by half-hourly input of $I, T, \mathrm{VPD}, C_{\mathrm{a}}, p_{\mathrm{a}}$, and $v$, and daily input of currentyear and one-year-old needle LAI. At each time step, the model calculates leaf-level gross photosynthesis $\left(A_{\mathrm{b}}\right)$ and $E$ for current-year and one-year-old sunlit and shaded needles in each canopy layer. These values are integrated over the canopy and over time to obtain instant, daily, and yearly GEP and $E_{\text {can }}$. Table 2 lists all constant model parameters with their references.

\subsection{Canopy model: parameterization and validation}

The parameterization of the canopy model was partially based on previous site study results and values from the literature (see Table 2). The stomatal model (Eqs. A15-A16) making part of the leaf physiological submodel (Eqs. A7A20) was parameterized to new site-specific gas exchange measurements in order to obtain reliable model results. Therefore, needle-level gas exchange diurnals and responses to VPD were assessed. On nine occasions throughout the summer 2007 , after a morning $A_{\mathrm{n}} / C_{\mathrm{i}}$ curve assessment, needles were held in the LI-6400 chamber and diurnal gas exchange courses were tracked under ambient conditions. Chamber $\mathrm{CO}_{2}$ concentration was set to $360 \mathrm{ppm}$. Three out of the nine diurnals included night-time measurements and on two occasions a day-night-day period $(36 \mathrm{~h})$ was covered. Needle gas exchange responses to VPD were measured on three needle samples in September 2007. Leaf chamber VPD was varied within a range of 0.5 up to $4.0 \mathrm{kPa}$ at saturating PAR $\left(1000 \mu \mathrm{mol} \mathrm{m}{ }^{-2} \mathrm{~s}^{-1}\right)$, chamber air temperature between 20 and $25^{\circ} \mathrm{C}$, and chamber $\mathrm{CO}_{2}$ concentration of $360 \mathrm{ppm}$. With these measurements, the stomatal model was parameterized. An average input value for the night-time conductance to $\mathrm{CO}_{2}\left(g_{0}\right)$ was directly obtained from the night-time measurements. An average input value for the empirical parameters $a_{1}$ and $\mathrm{VPD}_{0}$ was obtained by fitting the stomatal model to the gas exchange diurnals and the measured VPD responses, respectively, through minimization of the sum of squared differences between simulated and measured $g_{\text {st }}$.

The full leaf physiological submodel was validated against the two day-night-day periods. First, the empirical parameter $a_{1}$ was optimized again to the first day of each period by fitting the stomatal model through minimization of the sum of squared differences between simulated and measured $g_{\text {st }}$. The leaf physiological submodel was subsequently validated to the second day of each period using this $a_{1}$ value, the $V_{\mathrm{m} 25}$ and $J_{\mathrm{m} 25}$ values derived from the $A_{\mathrm{n}} / C_{\mathrm{i}}$ curves assessed on the needles before the continuous measurements were started, and the other parameter values as given in Table 2. The submodel's performance was judged by evaluating simulated versus measured half-hourly averaged net photosynthesis $\left(A_{\mathrm{n}}\right)$ and $E$.

\subsection{Photosynthetic parameter input scenarios}

The canopy model was run for one phenological year (1 May 2007 to 30 April 2008) with the half-hourly meteorological input and daily LAI input provided in Fig. 1, and the parameterization given in Table 2. Yearly GEP and $E_{\text {can }}$ were simulated under four $V_{\mathrm{m} 25}-J_{\mathrm{m} 25}$ input scenarios in which the measured needle age-related and seasonal variation of $V_{\mathrm{m} 25}$ and $J_{\mathrm{m} 25}$ were included or omitted. In the first scenario (scen-AS), which was the reference scenario, both seasonal 
Table 2. List of input parameter constants, with their reference.

\begin{tabular}{|c|c|c|c|}
\hline symbol & value & units & reference \\
\hline$a_{1}$ & 2.7 & dimensionless & optimized to diurnal gas exchange measurements \\
\hline$d$ & 0.0015 & $\mathrm{~m}$ & measured \\
\hline$E_{\mathrm{aVm}}$ & 32125 & $\mathrm{~J} \mathrm{~mol}^{-1}$ & Janssens et al. (1998) \\
\hline$E_{\mathrm{aJm}}$ & 37000 & $\mathrm{~J} \mathrm{~mol}^{-1}$ & de Pury and Farquhar (1997) \\
\hline$E_{\mathrm{aRd}}$ & 71600 & $\mathrm{~J} \mathrm{~mol}^{-1}$ & optimized to night-time gas exchange measurements \\
\hline$E_{\mathrm{aKo}}$ & 36000 & $\mathrm{~J} \mathrm{~mol}^{-1}$ & Medlyn et al. (2002) \\
\hline$E_{\mathrm{aKc}}$ & 59400 & $\mathrm{~J} \mathrm{~mol}^{-1}$ & Medlyn et al. (2002) \\
\hline$E_{\mathrm{a} \Gamma *}$ & 37830 & $\mathrm{~J} \mathrm{~mol}^{-1}$ & Medlyn et al. (2002) \\
\hline$f$ & 0.15 & dimensionless & de Pury and Farquhar (1997) \\
\hline$g_{0}$ & 0.015 & $\mathrm{~mol} \mathrm{~m}^{-2} \mathrm{~s}^{-1}$ & measured \\
\hline$H$ & 710 & $\mathrm{~J} \mathrm{~mol}^{-1}$ & de Pury and Farquhar (1997) \\
\hline$k_{\mathrm{d}}$ & 0.7 & dimensionless & de Pury and Farquhar (1997) \\
\hline$K_{\mathrm{c} 25}$ & 405 & ppm & Medlyn et al. (2002) \\
\hline$K_{\mathrm{O} 25}$ & 278400 & ppm & Medlyn et al. (2002) \\
\hline$O$ & 205000 & ppm & de Pury and Farquhar (1997) \\
\hline$R$ & 8.314 & $\mathrm{~J} \mathrm{~mol}^{-1} \mathrm{~K}^{-1}$ & Jones (1992) \\
\hline \multirow{2}{*}{$R_{\mathrm{d} 25} / V_{\mathrm{m} 25}$} & 0.025 (current-year) & dimensionless & derived from gas exchange measurements \\
\hline & 0.03 (one-year-old) & dimensionless & \\
\hline$S$ & 220000 & $\mathrm{~J} \mathrm{~mol}^{-1} \mathrm{~K}^{-1}$ & de Pury and Farquhar (1997) \\
\hline $\mathrm{VPD}_{0}$ & 1.9 & $\mathrm{kPa}$ & optimized to stomatal VPD response measurements \\
\hline$\alpha_{\mathrm{PAR}}$ & 0.85 & dimensionless & Jones (1992) \\
\hline$\Gamma$ & 47.0 & $\mathrm{ppm}$ & derived from measured $A / C_{\mathrm{i}}$ responses \\
\hline$\Gamma^{\prime}$ & 42.8 & ppm & Medlyn et al. (2002) \\
\hline$\theta$ & 0.5 & dimensionless & optimized to diurnal gas exchange measurements \\
\hline$\Omega$ & 0.83 & dimensionless & Jonckheere et al. (2005a) \\
\hline
\end{tabular}

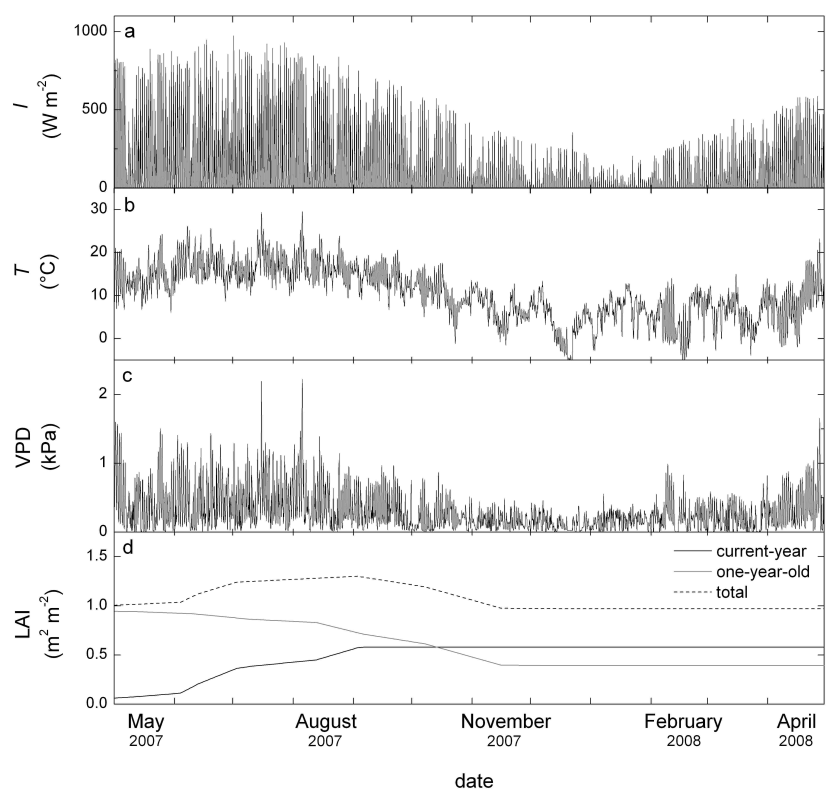

Fig. 1. Time courses of the half-hourly meteorological variables (a) incoming solar irradiance $(I),(\mathbf{b})$ air temperature $(T)$, (c) air vapour pressure deficit (VPD), and of (d) leaf area index (LAI) of currentyear needles (black line), one-year-old needles (grey line) and all needles (dotted line), over the phenological year May 2007-April 2008 . and needle age-related variation were included. In the second scenario (scen-A), only needle age-related variation was included. In the third scenario (scen-S), only seasonal variation was included. In the fourth scenario (scen-B), which was the basic scenario, both needle age-related and seasonal variation were omitted. For the scenarios in which seasonal variation was included (scen-AS, scen-S), $V_{\mathrm{m} 25}$ and $J_{\mathrm{m} 25}$ measurements from consecutive sampling dates were pooled when statistically not significantly different, as indicated by an analysis of variance (ANOVA) post hoc comparison test. Continuous time courses of $V_{\mathrm{m} 25}$ and $J_{\mathrm{m} 25}$ were obtained by linear interpolation. For the scenarios in which seasonal variation was omitted (scen-A, scen-B), $V_{\mathrm{m} 25}$ and $J_{\mathrm{m} 25}$ input values were based on the July and August 2007 measurements only, as photosynthetic capacity measurements for model parameterization are typically done in summer. Values of the two dates were pooled. For the scenarios in which needleage related variation was omitted (scen-S, scen-B), $V_{\mathrm{m} 25}$ and $J_{\mathrm{m} 25}$ measurements from current-year and one-year-old needles were pooled and the weighted average was calculated with current-year and one-year-old needle LAI as weighting factor, as in Ogée et al. (2003). In all four $V_{\mathrm{m} 25}-J_{\mathrm{m} 25}$ input scenarios, current-year and one-year-old needles were given the same values for the other parameters in the leaf physiological submodel with the exception of the $R_{\mathrm{d} 25} / V_{\mathrm{m} 25}$ ratio (see Table 2). 


\subsection{Statistics}

All statistical analyses were performed using the statistical package of the ORIGIN® software (version 7, OriginLab Corporation, Northampton, MA, USA) and SAS (version 9.1, SAS Institute Inc., Cary, NC, USA). To test for significant differences between two or more means, a two-tailed Student's t-test or a one-way ANOVA was applied. To unravel the effect of needle age and seasonality on $V_{\mathrm{m} 25}, J_{\mathrm{m} 25}$, and the $J_{\mathrm{m} 25} / V_{\mathrm{m} 25}$ ratio, we performed an analysis of covariance (ANCOVA) with needle age as treatment and the day of the phenological year (1 May 2007=1) as the covariate. In case of a statistically significant difference $(p<0.05)$, the analyses were followed by post hoc comparisons of all means by the Tukey-Kramer HSD test. A Monte Carlo technique was used to estimate the uncertainty on simulated yearly GEP and $E_{\text {can }}$ from the uncertainty distributions of the input parameters $V_{\mathrm{m} 25}$ and $J_{\mathrm{m} 25}$. The number of Monte Carlo model runs under each scenario was set to 500, the minimum number after which the standard deviation on simulated yearly GEP and $E_{\text {can }}$ converged. We assumed normality of the probability density function of $V_{\mathrm{m} 25}$ and $J_{\mathrm{m} 25}$, which was tested for with a Shapiro-Wilk test. The performance of the leaf physiological submodel was evaluated by the coefficient of determination $\left(R^{2}\right)$, the slope and the intercept of the linear regression of simulated versus measured $A_{\mathrm{n}}$ and $E$, the root-mean-square-error (RMSE), and Willmott's index of agreement $(d)$ (Willmott, 1981). This index ranges from 0 to 1,1 indicating perfect agreement. Statistical significance for all tests was set at the 0.05 level. In text and tables, given errors on means are standard errors (SE).

\section{Results}

\subsection{Meteorological site conditions}

Phenological year and growing season mean air temperature during the study period (May 2007-April 2008) were 10.4 and $13.9^{\circ} \mathrm{C}$, respectively, which are 1.4 and $1.0^{\circ} \mathrm{C}$ below the ten-year mean. Phenological year and growing season total precipitation mounted to 903 and $502 \mathrm{~mm}$, respectively, the former of which is about $10 \%$ above the long-term mean. Growing season total precipitation followed the long term mean of $505 \mathrm{~mm}$. The study period was characterized by the absence of extreme air temperatures and dry atmospheric conditions: $T$ virtually never exceeded $25^{\circ} \mathrm{C}$ and VPD hardly exceeded $1.5 \mathrm{kPa}$ (Fig. 1b, c).

\subsection{Leaf area index}

Total LAI during the study period varied between 0.94 and $1.31 \mathrm{~m}^{2} \mathrm{~m}^{-2}$ (Fig. 1d). Total LAI was minimal just before bud burst in spring 2007 and peaked after full expansion of current-year needles in late summer. By this time, currentyear needle LAI had increased to $0.55 \mathrm{~m}^{2} \mathrm{~m}^{-2}$, contribut- ing to $42 \%$ of total LAI. By the end of autumnal needle shed, one-year-old needle projected LAI had dropped to 0.39 $\mathrm{m}^{2} \mathrm{~m}^{-2}$ and total LAI reached a minimum again. In winter 2007 and spring 2008, current-year needles and one-yearold needles made up $60 \%$ and $40 \%$ of total canopy LAI, respectively. Destructive sampling in August 2007 showed a slightly uneven upper/lower canopy distribution of currentyear and one-year-old needle LAI (58/42\% and $47 / 53 \%$, respectively).

\subsection{Upper versus lower canopy}

Photosynthetic capacity and needle $\mathrm{N}$ content differences between the upper and the lower canopy were specifically examined during the first sampling (June 2007), in order to confirm the findings of a previous site study, which reported a non-significant canopy effect on $V_{\mathrm{m} 25}$ and $J_{\mathrm{m} 25}$ (Janssens et al., 1998) and so to possibly reduce the number of measurements during the following samplings. As current-year needles were still too small to be sampled, all measurements were made on one-year-old needles. Maximum carboxylation capacity at $25^{\circ} \mathrm{C}$ was not significantly different between the upper canopy $\left(67.8 \pm 2.3 \mu \mathrm{mol} \mathrm{m}^{-2} \mathrm{~s}^{-1} ; n=12\right)$ and the lower canopy $\left(71.3 \pm 2.5 \mu \mathrm{mol} \mathrm{m}^{-2} \mathrm{~s}^{-1} ; n=9\right)(p=0.47)$. Also $J_{\mathrm{m} 25}$ was not significantly different between the upper canopy $\left(147.2 \pm 2.1 \mu \mathrm{mol} \mathrm{m}^{-2} \mathrm{~s}^{-1}\right)$ and the lower canopy $\left(157.4 \pm 7.9 \mu \mathrm{mol} \mathrm{m}^{-2} \mathrm{~s}^{-1}\right)(p=0.41)$. In line with the photosynthetic parameters, $N_{\mathrm{a}}$ did not significantly differ between the upper canopy $\left(648.9 \pm 50.6 \mathrm{mmol} \mathrm{m}^{-2}\right)$ and the lower canopy $\left(573.6 \pm 41.2 \mathrm{mmol} \mathrm{m}^{-2}\right)(p=0.13)$. On the basis of these results, which were confirmed a posteriori when considering all data (results not shown), we decided to pool measurements from the upper and lower canopy.

\subsection{Needle-age related and seasonal photosynthetic parameter variation}

Seasonal variations in $V_{\mathrm{m} 25}, J_{\mathrm{m} 25}$, and the $J_{\mathrm{m} 25} / V_{\mathrm{m} 25}$ ratio are depicted in Fig. 2 for current-year needles (white bars) and one-year-old needles (grey bars). An ANCOVA was performed to unravel the effect of needle age and seasonality on $V_{\mathrm{m} 25}, J_{\mathrm{m} 25}$, and the $J_{\mathrm{m} 25} / V_{\mathrm{m} 25}$ ratio. The analysis revealed a significant effect of needle age on $V_{\mathrm{m} 25}$ after controlling for the seasonality effect $(p<0.0001)$. Maximum carboxylation capacity at $25^{\circ} \mathrm{C}$ was significantly higher in current-year than in one-year-old needles. Adjusted $V_{\mathrm{m} 25}$ means were $81.3 \pm 2.5$ and $63.1 \pm 1.9 \mu \mathrm{mol} \mathrm{m}^{-2} \mathrm{~s}^{-1}$, respectively. Moreover, the seasonality effect was significant $(p<0.0001)$, with $V_{\mathrm{m} 25}$ decreasing with day of the phenological year (slope $=-0.07623 \pm 0.115 \mu \mathrm{mol} \mathrm{m} \mathrm{m}^{-2} \mathrm{~s}^{-1} \mathrm{~d}^{-1}$ ). The analysis also revealed a significant effect of needle age on $J_{\mathrm{m} 25}$ after controlling for the effect of seasonality $(p<0.05)$. Maximum electron transport capacity at $25^{\circ} \mathrm{C}$ was significantly higher in current-year than in one-year-old needles. Adjusted $J_{\mathrm{m} 25}$ means were $163.3 \pm 5.8$ and $144.9 \pm 4.6 \mu \mathrm{mol} \mathrm{m}^{-2} \mathrm{~s}^{-1}$, 


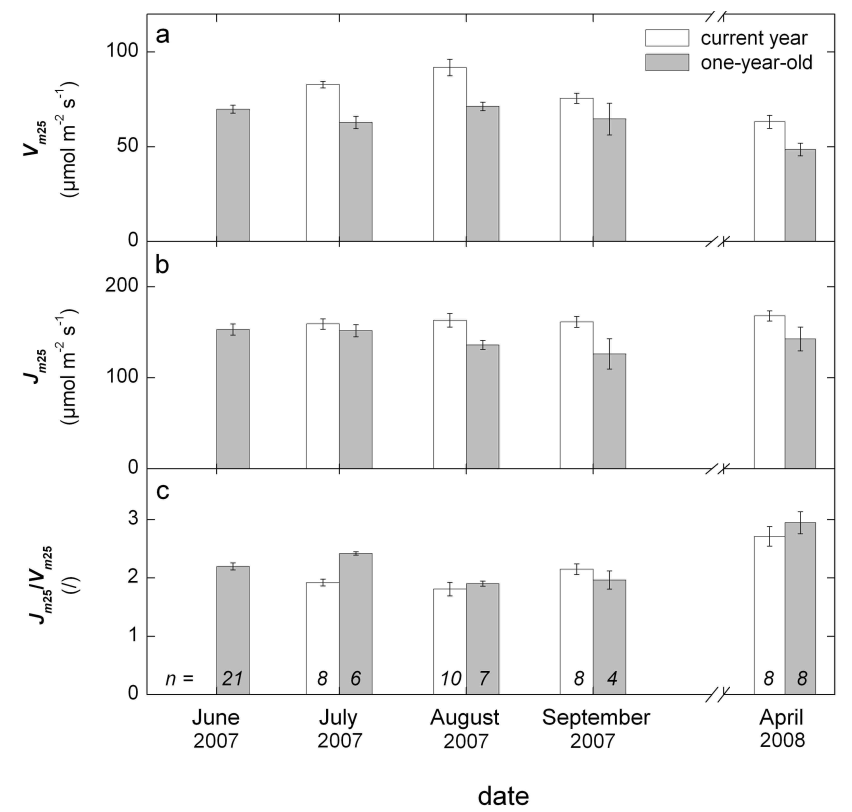

Fig. 2. Seasonal variation of (a) maximum carboxylation capacity at $25^{\circ} \mathrm{C}\left(V_{\mathrm{m} 25}\right)$, (b) maximum electron transport capacity at $25^{\circ} \mathrm{C}\left(J_{\mathrm{m} 25}\right)$, and (c) the $J_{\mathrm{m} 25} / V_{m 25}$ ratio, for current-year needles (white bars) and one-year-old needles (grey bars). Error bars represent SE. In June 2007, current-year needles were too small to be sampled.

respectively. In contrast with $V_{\mathrm{m} 25}$, the seasonality effect on $J_{\mathrm{m} 25}$ was not significant $(p=0.79)$. Furthermore, also a significant needle age effect on the $J_{\mathrm{m} 25} / V_{\mathrm{m} 25}$ ratio was detected, after controlling for the seasonality effect $(p<$ 0.001). The ratio was significantly higher in one-year-old than in current-year needles. The adjusted ratio means were $2.05 \pm 0.08$ and $2.34 \pm 0.07$, respectively. The effect of seasonality on the ratio was significant $(p<0.0001)$, with a positive relation between the ratio and day of the phenological year (slope $=0.0028 \pm 0.0004 \mathrm{~d}^{-1}$ ).

\subsection{Photosynthetic parameters versus needle $\mathbf{N}$ content}

Based on the measurements in July and August 2007, the summer relationship between photosynthetic parameters and needle $\mathrm{N}$ content was quantified along the two needle ages (Table 3 ). The parameters $V_{\mathrm{m} 25}$ and $J_{\mathrm{m} 25}$ were significantly higher in current-year than in one-year-old needles, while at the same time biomass- and area-based $\mathrm{N}$ content $\left(N_{\mathrm{b}}\right.$ and $N_{\mathrm{a}}$ ) were significantly higher in one-year-old needles. As a result, the $V_{\mathrm{m} 25} / N_{\mathrm{a}}$ ratio and the $J_{\mathrm{m} 25} / N_{\mathrm{a}}$ ratio were much higher in current-year than in one-year-old needles. Maximum carboxylation capacity at $25^{\circ} \mathrm{C}$ was even negatively correlated with $N_{\mathrm{a}}$ when considering the data of both needle ages together $(r=-0.61, p<0.001$; Fig. $3 \mathrm{a})$. The correlation between $J_{\mathrm{m} 25}$ and $N_{\mathrm{a}}$ was not significant $(r=-0.11$, $p=0.53$; Fig. 3b).

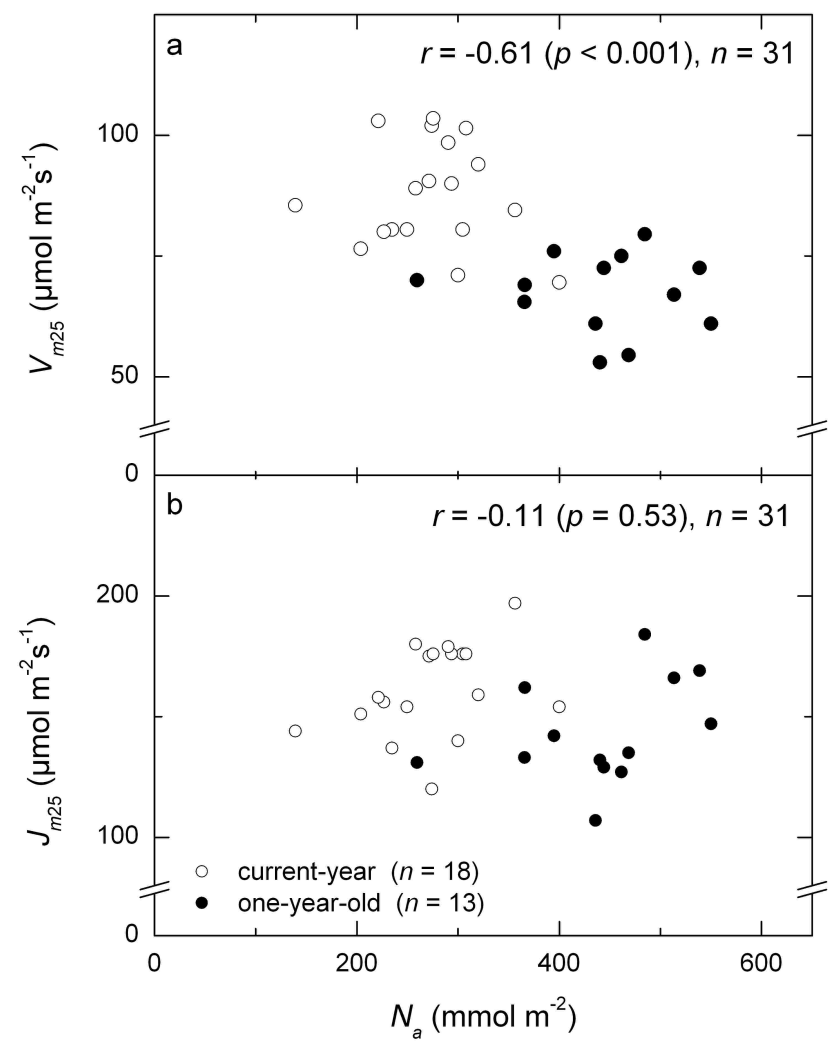

Fig. 3. Scatter plots of (a) maximum carboxylation capacity at $25^{\circ} \mathrm{C}\left(V_{\mathrm{m} 25}\right)$ versus area-based needle nitrogen content $\left(N_{\mathrm{a}}\right)$, and (b) potential electron transport capacity at $25^{\circ} \mathrm{C}\left(J_{\mathrm{m} 25}\right)$ versus $N_{\mathrm{a}}$, for current-year needles (open symbols) and one-year-old needles (filled symbols). Data are from July and August 2007. $r=$ correlation coefficient.

\subsection{Canopy gas exchange simulations}

The leaf physiological submodel of the canopy model satisfactorily reproduced half-hourly averaged net photosynthesis $\left(A_{\mathrm{n}}\right)$ and transpiration $(E)$, as indicated by the $R^{2}$ and $d$ values, being close to 1 , and the low RMSE values (Fig. 4). Predictions of $E$ were slightly less accurate than predictions of $A_{\mathrm{n}}$. This is most probably due to the fact that, contrary to $A_{\mathrm{n}}, g_{\mathrm{st}}$ and, hence, $E$ respond very slowly to light changes. These dynamics could not be fully captured by the submodel assuming steady state conditions. It should be noted that the submodel was tested with $a_{1}$ values optimized to the first day of each biurnal. If the submodel was tested with the average $a_{1}$ value used in the canopy model runs (see Table 2), it would have been less accurate. Nonetheless, Fig. 4 shows how well the submodel could behave on the needle-level.

After validating the submodel, the canopy model was run under the four $V_{\mathrm{m} 25}-J_{\mathrm{m} 25}$ input scenarios, for which the $V_{\mathrm{m} 25}$ and $J_{\mathrm{m} 25}$ input values are given in Table 4. Under the reference scenario, including both needle agerelated and seasonal variation (scen-AS), simulated yearly 

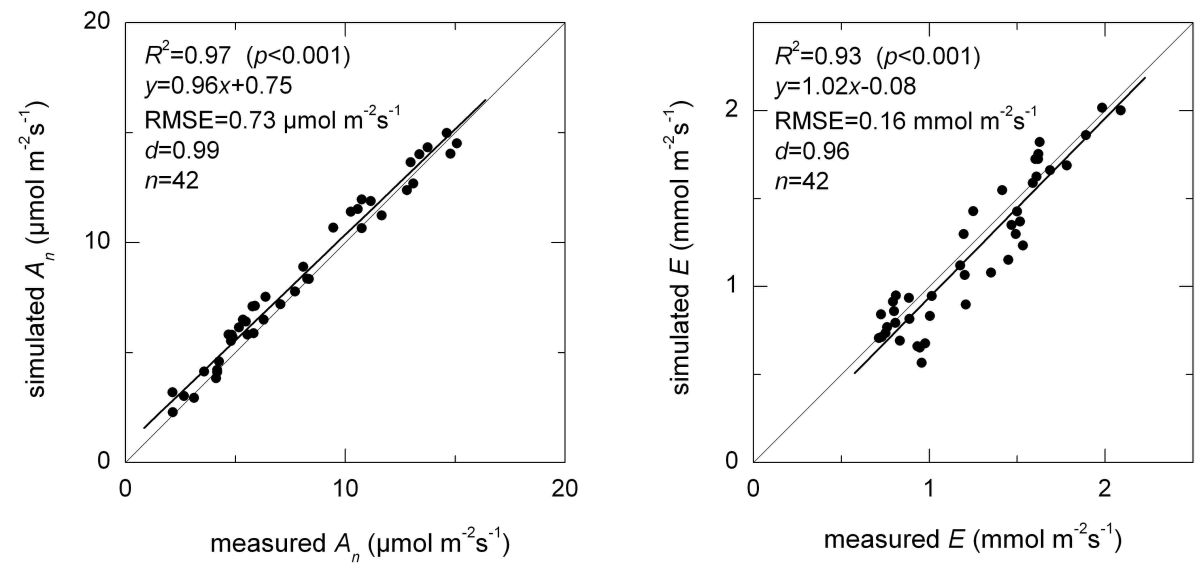

Fig. 4. Validation of the leaf physiological submodel. Scatter plot of (a) simulated versus measured half-hourly averaged net leaf photosynthesis $\left(A_{\mathrm{n}}\right)$, and (b) simulated versus measured half-hourly averaged transpiration $(E)$. The submodel was validated against the data of the second day of two day-night-day periods $(36 \mathrm{~h})$ of continuous gas exchange measurements. Grey lines are the 1:1 lines. Black lines are the linear regression curves. $R^{2}=$ coefficient of determination; RMSE=root-mean-square-error; $d=$ Willmott's index of agreement.

Table 3. Photosynthetic parameters versus needle nitrogen $(\mathrm{N})$ content. Results (mean $\pm \mathrm{SE}$ ) for current-year needles and one-year-old needles, from summer measurements (July and August 2007), with $p$-values of $t$-test comparison. For an explanation of the symbols and parameters, see Table 1.

\begin{tabular}{|c|c|c|c|c|}
\hline parameter & $\begin{array}{l}\text { current year } \\
(n=18)\end{array}$ & $\begin{array}{r}\text { one-year-old } \\
\qquad(n=13)\end{array}$ & $p$-value & \\
\hline$V_{\mathrm{m} 25}$ & $\left(\mu \mathrm{mol} \mathrm{m}{ }^{-2} \mathrm{~s}^{-1}\right)$ & $87.8 \pm 2.6$ & $67.4 \pm 2.3$ & $<0.0001$ \\
\hline$J_{\mathrm{m} 25}$ & $\left(\mu \mathrm{mol} \mathrm{m}{ }^{-2} \mathrm{~s}^{-1}\right)$ & $161.6 \pm 4.6$ & $143.4 \pm 5.9$ & $<0.05$ \\
\hline$N_{\mathrm{b}}$ & $\left(\mathrm{g} \mathrm{g}^{-1} \mathrm{DW}\right)$ & $1.56 \pm 0.05$ & $1.85 \pm 0.06$ & $<0.001$ \\
\hline$N_{\mathrm{a}}$ & $(\mathrm{mmol} \mathrm{m}-2)$ & $273.7 \pm 13.8$ & $440.3 \pm 22.1$ & $<0.0001$ \\
\hline$V_{\mathrm{m} 25} / N_{\mathrm{a}}$ & $\left(\mu \mathrm{mol} \mathrm{mmol}{ }^{-1} \mathrm{~s}^{-1}\right)$ & $0.34 \pm 0.02$ & $0.16 \pm 0.03$ & $<0.0001$ \\
\hline$J_{\mathrm{m} 25} / N_{\mathrm{a}}$ & $\left(\mu \mathrm{mol} \mathrm{mmol} \mathrm{mol}^{-1} \mathrm{~s}^{-1}\right)$ & $0.61 \pm 0.02$ & $0.33 \pm 0.02$ & $<0.0001$ \\
\hline
\end{tabular}

GEP and $E_{\text {can }}$ amounted to $1.561 \pm 0.004 \mathrm{~kg} \mathrm{C} \mathrm{m}^{-2} \mathrm{y}^{-1}$ and $201.8 \pm 0.5 \mathrm{~kg} \mathrm{H}_{2} \mathrm{O} \mathrm{m}^{-2} \mathrm{y}^{-1}$, respectively (Table 5). Yearly GEP and $E_{\text {can }}$ simulated under the scenario including needle age-related variation only (scen-A) were not significantly different from these values. Relative to scen-AS, yearly GEP and $E_{\text {can }}$ were significantly underestimated under the scenario including seasonal variation only (scen-S), and significantly overestimated under the basic scenario, omitting both needle age-related and seasonal variation (scen-B). The percentage-wise differences with the scen-AS results, however, were small (within 2.5\%). Measured yearly GEP, which amounted to $1.352 \mathrm{~kg} \mathrm{C} \mathrm{m}^{-2} \mathrm{y}^{-1}$, was considerably overestimated by the canopy model under all scenario's $(+13.0 \%$ to $+17.5 \%)$.

Daily GEP simulated under scen-AS clearly followed the seasonal course of measured GEP (Fig. 5a), yet simulated GEP was slightly lower in spring 2007 and higher from August 2007 on (Fig. 5b). Daily GEP courses were very similar under all scenarios. For reasons of clarity, we depicted the simulated daily GEP differences with scen-AS instead of absolute daily GEP values (Fig. 5c-e). The seasonal courses of daily GEP simulated under scen-A and scen-AS were virtually equal (Fig. 5c). Under scen-S, the model simulated slightly lower daily GEP in summer 2007, relative to scenAS (Fig. 5d). Under scen-B, daily GEP values were slightly higher in early summer (Fig. 5e). The differences in simulated daily GEP were all within $0.5 \mathrm{~g} \mathrm{C} \mathrm{m}^{-2} \mathrm{~d}^{-1}$. Daily $E_{\text {can }}$ simulations showed relative patterns analogous to daily GEP and are not presented to avoid redundancy.

\section{Discussion}

\subsection{Upper versus lower canopy}

We did not observe a significant difference between the photosynthetic parameters $V_{\mathrm{m} 25}$ and $J_{\mathrm{m} 25}$ or the $\mathrm{N}$ content of upper and lower canopy needles. These findings are 
Table 4. Input values of carboxylation capacity at $25^{\circ} \mathrm{C}\left(V_{\mathrm{m} 25} ; \mu \mathrm{mol} \mathrm{m} \mathrm{m}^{-2} \mathrm{~s}\right)$ and electron transport capacity at $25^{\circ} \mathrm{C}\left(J_{\mathrm{m} 25}\right.$; $\mu \mathrm{mol} \mathrm{m} \mathrm{m}^{-2} \mathrm{~s}^{-1}$ ) (value $\pm \mathrm{SE}$ ) for the four scenarios. For the scenario including both seasonal and needle age-related variation (scen-AS) and the scenario including needle age-related variation only (scen-S), values between dashed lines are obtained from pooling the measurements from the consecutive sampling dates underscored by the dashed lines and are constant over period between the consecutive sampling dates. Values between non-pooled consecutive sampling dates are linearly intrapolated. For the scenario including needle age-related variation only (scen-A) and the scenario omitting both seasonal and needle age-related variation (scen-B), values are based on measurements from July and August 2007 only.

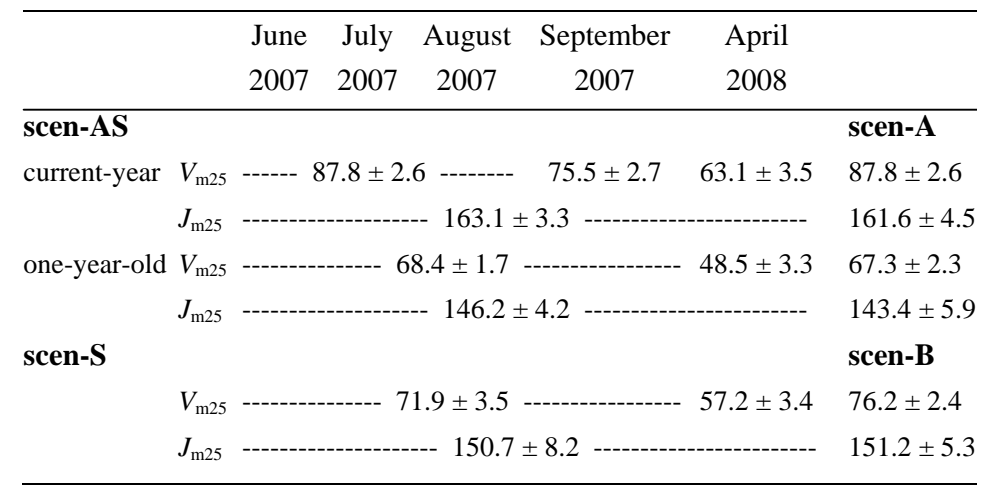

Table 5. Measured and simulated yearly gross ecosystem productivity (GEP; $\mathrm{kg} \mathrm{C} \mathrm{m}^{-2} \mathrm{y}^{-1}$ ) and simulated canopy transpiration ( $E_{\mathrm{can}}$; $\mathrm{kg} \mathrm{H}_{2} \mathrm{O} \mathrm{m}^{-2} \mathrm{y}^{-1}$ ) under the four scenarios (mean $\pm \mathrm{SE}$ ), with the percentagewise difference and $p$-values of $t$-test comparison with scen-AS results. Also given are the percentagewise difference and the $p$-values of One Sample $t$-test comparison of simulated GEP with measured GEP. $n=500$.

\begin{tabular}{|c|c|c|c|c|c|c|c|c|}
\hline \multirow{3}{*}{$\begin{array}{l}\text { measured } \\
\text { scen-AS }\end{array}$} & \multicolumn{5}{|c|}{ yearly GEP } & \multicolumn{3}{|c|}{ yearly $E_{\text {can }}$} \\
\hline & 1.351 & & & $\%$ & $p$-value & & & \\
\hline & $1.561 \pm 0.004$ & $\%$ & $p$-value & +15.5 & $<0.0001$ & $201.8 \pm 0.5$ & $\%$ & $p$-value \\
\hline scen-A & $1.568 \pm 0.004$ & +0.4 & 0.29 & +16.1 & $<0.0001$ & $202.9 \pm 0.4$ & +0.5 & 0.07 \\
\hline scen-S & $1.527 \pm 0.004$ & -2.2 & $<0.0001$ & +13.0 & $<0.0001$ & $197.2 \pm 0.5$ & -2.3 & $<0.0001$ \\
\hline scen-B & $1.587 \pm 0.005$ & +1.6 & $<0.0001$ & +17.5 & $<0.0001$ & $205.9 \pm 0.5$ & +2.0 & $<0.0001$ \\
\hline
\end{tabular}

corroborated by a previous site study (Janssens et al., 1998). Though we only sampled one-year-old needles, we have no reason to assume results would be different for currentyear needles. We believe the absence of any canopy position effect is a consequence of the canopy sparsity (maximal $\mathrm{LAI}=1.31 \mathrm{~m}^{2} \mathrm{~m}^{-2}$, Fig. 1d). In the virtual absence of a light gradient within the sparse canopy, no vertical canopy $\mathrm{N}$ or photosynthetic capacity profile is (or better, has to be) developed within the needle age class to optimize canopy photosynthesis.

\subsection{Needle-age related and seasonal photosynthetic parameter variation}

We found significantly lower $V_{\mathrm{m} 25}$ and $J_{\mathrm{m} 25}$ values in oneyear-old needles than in current-year needles, following the general trend of decreasing photosynthetic capacity with needle age (Rundel and Yoder, 2000; Niinemets, 2002). This trend, which sometimes hovers on the edge of significance (e.g., Letts et al., 2009), was less pronounced for $J_{\mathrm{m} 25}$ than for $V_{\mathrm{m} 25}$. In addition to the effect of needle age, we found a seasonality effect on $V_{\mathrm{m} 25}$, but not on $J_{\mathrm{m} 25}$. The seasonal variation of $V_{\mathrm{m} 25}$, however, was weaker than reported in other Pinus studies (Ellsworth, 2000; Misson et al., 2006; Han et al., 2008). Overall, the observed $V_{\mathrm{m} 25}$ and $J_{\mathrm{m} 25}$ values are in agreement with previous observations at the site (Janssens et al., 1998) and with literature values for $P$. sylvestris (Wang et al., 1995; Kellomäki and Wang, 1997; Jach and Ceulemans, 2000; Niinemets et al., 2001). The $V_{\mathrm{m} 25}$ values fall within the higher range of reported values, summarized by Niinemets (2002) and Katge et al. (2009), but are typical for $\mathrm{N}$-rich sites.

In general, the needle age-related decline of photosynthetic capacity in conifers is assumed to be caused by (1) decreasing needle $\mathrm{N}$ content through allocation to younger needles in order to maximize whole canopy carbon gain (Field, 


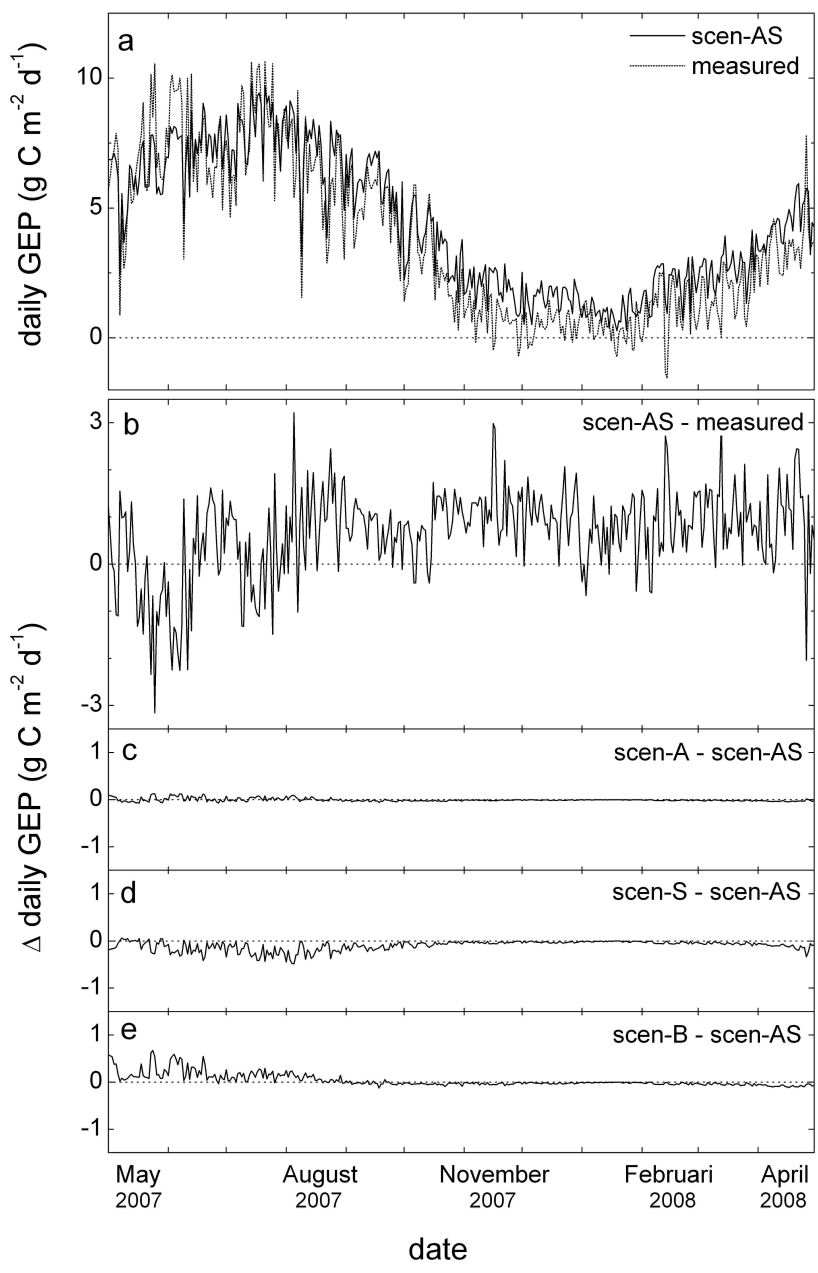

Fig. 5. Time courses of (a) daily gross ecosystem productivity (GEP) simulated under scen-AS (solid line) and measured daily GEP (short-dotted line), (b) the difference between daily GEP simulated under scen-AS and measured daily GEP ( $\Delta$ daily GEP), and $\Delta$ daily GEP between scen-AS and (c) scen-A, (d) scen-S, and (e) scen-B. Scen-AS is the reference scenario, including both seasonal and needle age-related variation in $V_{\mathrm{m} 25}$ and $J_{\mathrm{m} 25}$. In scen-A, only needle age-related variation is included. In scen-S, only seasonal variation is included. In scen- $\mathrm{B}$, both seasonal and needle agerelated variation are omitted.

1983), and (2) decreasing $\mathrm{CO}_{2}$ concentration at the carboxylation sites through declining internal conductance to $\mathrm{CO}_{2}$ as needles become denser and cell walls thicken when needles age (Warren, 2006; Niinemets et al., 2009). Although we measured increasing needle $\mathrm{N}$ content with needle age (Table 3), our results do certainly not give unequivocal proof against the first assumption, since our needle samples were not specifically analyzed for photosynthesis-related $\mathrm{N}$ and might have been "contaminated" (see next paragraph). We could not verify the second assumption, a declining internal conductance to $\mathrm{CO}_{2}$ with needle age, with measurements. Yet, such a decline might explain the observed smaller ef- fect of needle age on $J_{\mathrm{m} 25}$ than on $V_{\mathrm{m} 25}$. Both photosynthetic parameters were obtained by optimizing the biochemical photosynthesis model of Farquhar (Farquhar et al., 1980) to $A_{\mathrm{n}} / C_{\mathrm{i}}$ curves. Here, internal conductance was ignored in the calculation of leaf intercellular $\mathrm{CO}_{2}$ concentration $\left(C_{\mathrm{i}}\right)$, which we assume also to be the $\mathrm{CO}_{2}$ concentration at the carboxylation sites. As a consequence, our calculation would yield a relative overestimation of $C_{\mathrm{i}}$ in one-year-old needles if internal conductance to $\mathrm{CO}_{2}$ was really lower in one-yearold needles. This would lead to a relative underestimation of optimized $V_{\mathrm{m} 25}$ but not of $J_{\mathrm{m} 25}$, as the optimization of $J_{\mathrm{m} 25}$ but not of $V_{\mathrm{m} 25}$ to an $A_{\mathrm{n}} / C_{\mathrm{i}}$ curve is largely independent of $C_{\mathrm{i}}$. These assumed underlying physiological causes of the effect of needle age might provide an explanation for the observed seasonality effect as well, as seasonal variation mainly results from needle ageing within the growing season.

\subsection{Photosynthetic parameters versus needle $\mathrm{N}$ content}

We found that the $V_{\mathrm{m} 25} / N_{\mathrm{a}}$ ratio and the $J_{\mathrm{m} 25} / N_{a}$ ratio were much higher in current-year than in one-year old needles. When considering the data of both needle ages together, a negative correlation between $V_{\mathrm{m} 25}$ and $N_{\mathrm{a}}$ and a nonsignificant correlation between $J_{\mathrm{m} 25}$ and $N_{\mathrm{a}}$ was observed. These rather unexpected trends should be ascribed to the observed needle $\mathrm{N}$ contents, which were lower in current-year needles than in one-year-old needles. Our observations deviate from the general finding that needle $\mathrm{N}$ content tends to decrease with needle age (Field, 1983; Helmisaari, 1990; Niinemets, 2002), but are not unprecedented for P. sylvestris (Gielen et al., 2000).

We bring forward two explanations for the observed lower needle $\mathrm{N}$ contents in current-year needles as compared to one-year-old needles. First, we hypothesize that under the conditions of high $\mathrm{N}$ availability prevailing at the site (Neirynck et al., 2008) the $\mathrm{N}$ demand of expanding currentyear-needles and shoots is partially met by supply of $\mathrm{N}$ taken up at high rates by the roots. This supply of soil-borne $\mathrm{N}$ might partially inhibit or render superfluous the commonly observed translocation of $\mathrm{N}$ stored in now-one-year-old needles the previous autumn to the expanding current-year needles (Vapaavuori et al., 1995; Warren et al., 2003). Furthermore, storage of excess $\mathrm{N}$ in one-year-old needles, which is usually limited to autumn (e.g., Näsholm and Ericsson, 1990; Vapaavuori et al., 1995), might already occur in summer under conditions of high $\mathrm{N}$ availability. As a result, one-yearold needles still or already contain significant amounts of $\mathrm{N}$ not associated with photosynthesis in summer. Second, we do not rule out the possibility that our needle samples have been "contaminated" with extracuticular $\mathrm{N}$ originating from epiphytic nitrophylic microflora occurring on the needle surfaces. The abundance of epiphytic microflora on conifer needles has been shown to positively correlate with the amount of nitrogen deposition (Bråkenhielm and Qinghong, 1995; Poikolainen et al., 1998). As nitrogen deposition rates in 
the experimental stand are very high $\left(30-40 \mathrm{~kg} \mathrm{ha}^{-1} \mathrm{y}^{-1}\right.$; Neirynck et al., 2007) and epiphytic microfloral biomass has been shown to accumulate with needle age (Göransson, 1992; Søchting, 1997), we believe this could contribute to some extent to the observed higher measured $\mathrm{N}$ content in one-year-old needles.

\subsection{Canopy gas exchange simulations}

With an average GEP of $1.56 \mathrm{~kg} \mathrm{Cm}^{-2} \mathrm{y}^{-1}$, our canopy model produced values very close to the mean GEP reported for temperate humid evergreen forests $\left(1.76 \pm 0.06 \mathrm{~kg} \mathrm{C} \mathrm{m}^{-2} \mathrm{y}^{-1}\right.$; the 25 to 75 percentiles lying at 1.39 and $2.13 \mathrm{~kg} \mathrm{C} \mathrm{m}^{-2} \mathrm{y}^{-1}$; Luyssaert et al., 2007). Simulated GEP showed a very similar seasonal pattern as the eddy covariance-based estimates of GEP made at the site, yet were higher during most of the year. This was not really surprising. Eddy covariance-based estimates of GEP are obtained by subtracting modelled ecosystem respiration estimates from the measured net ecosystem exchange. In our case, the respiration model was based on night-time $\mathrm{CO}_{2}$ flux measurements that are subsequently extrapolated to day time using temperature response functions. Night-time $\mathrm{CO}_{2}$ fluxes are typically underestimated during low turbulent conditions, but this problem is mitigated by excluding all wind still hours from the data series and subsequent gap filling. Alternative methods to partition the eddy covariance net ecosystem fluxes into the respiratory and photosynthetic components produced very similar estimates of GEP at our site (Lasslop et al., 2010). In the latter study, partitioning was based on subtracting the zero light intercept from a light-response curve fitted to daytime-only data. The issue here is that air temperature and vapor pressure deficit at zero light are different from those at high light. In any case, both approaches yielded very similar, eddy covariance-based GEP estimates. A potentially larger problem that may contribute to underestimated daytime respiration and subsequently also to underestimated GEP is that the footprint of the eddy covariance system exceeds the pine stand boundaries and includes a low-productive heath land. Especially during night time and early morning, when natural convection is small, the error associated herewith is potentially large. Nonetheless, overall, our simulated GEP and the eddy covariance-based GEP estimates agreed well.

Because the objective of this study was not to simulate the absolute GEP, but rather to study the effect of more versus less detailed parameterization on simulated GEP, the simulated GEP differences between the scenarios are more relevant than the absolute differences between measured and simulated GEP. Only the omittance of needle age-related photosynthetic parameter variation (scen-S, scen-B) led to significant differences in yearly GEP and $E_{\text {can }}$, relative to the reference scenario. These differences were small (within $2.5 \%$ ) and, hence, rather trivial from an ecological point of view. The small differences in yearly GEP and $E_{\text {can }}$ resulted from small differences in simulated daily GEP and $E_{\text {can }}$ in spring and summer when climatic conditions favoured gas exchange (Fig. 5c, d), which was somewhat expected. Even though the phenological year May 2007-April 2008 was slightly colder and wetter than the long-term mean, we doubt differences in yearly GEP and $E_{\text {can }}$ between the scenarios would become ecologically relevant if simulations were done under the long-term site meteorological conditions.

In a study similar to ours, Bernier et al. (2001) also found differences of less than $3 \%$ of canopy gas exchange simulated under a scenario including age-related variation (scenA) and a scenario with the photosynthetic capacity input of an average needle age (scen-B), for an Abies balsamea (L.) stand in Canada. In another analogous study, however, Ogée et al. (2003) used eddy covariance measurements to validate canopy fluxes for a Pinus pinaster (Ait.) stand in France, simulated under a scenario including both seasonal and needle age-related photosynthetic capacity variation (scen-AS) and a scenario including seasonality only (scen-S). They found that omitting needle age-related variation resulted in considerable loss in predictive quality. In search for an explanation for these differing results, we looked into the common structure of the process-based models applied in our study (Appendix A) and the studies of Ogée et al. (2003) and Bernier et al. (2001). It can easily be inferred that the effect of omitting needle age-related variation on canopy gas exchange, simulated with process-based models like the ones applied, depends on the (1) magnitude of the differences of photosynthetic capacity input values between the needle age classes, (2) the canopy density, and (3) the shape of the vertical LAI profiles of the different-aged needles in the canopy (along the light gradient). The three studies do differ in these aspects indeed. For example, the differences in photosynthetic parameter input values between the needle age classes were much higher in the study of Ogée et al. (2003) than in the study of Bernier et al. (2001) and our study. Ogée et al. (2003) applied $V_{\mathrm{m} 25}$ input values for one-year-old and two-year-old needles which were about $80 \%$ and $60 \%$ of the current-year needle value, respectively. Likewise, the $J_{\mathrm{m} 25}$ input values amounted only to about $60 \%$ and $35 \%$ of the current-year-needle value. In our study, the $V_{\mathrm{m} 25}$ and $J_{\mathrm{m} 25}$ input value for one-year-old needles were $79 \%$ and $89 \%$ of the current-year-needle input value. In Bernier et al. (2001), the least active, seven-year-old needles still retained $60 \%$ of the photosynthetic capacity of the most active, one-year-old needles. As regards canopy density, our Scots pine stand had a very low LAI (between 0.94 and 1.31 $\mathrm{m}^{2} \mathrm{~m}^{-2}$; Fig. 1d), whereas Ogée et al. (2003) ran simulations for a stand with a LAI varying between 2.6 and $3.2 \mathrm{~m}^{2} \mathrm{~m}^{-2}$, and Bernier et al. (2001) simulated gas exchange for a stand with $\mathrm{LAI}>5.5 \mathrm{~m}^{2} \mathrm{~m}^{-2}$. Also, only weakly differing vertical LAI profiles of current-year and one-year-old needles were observed in our sparse stand (see Sect. 3.2), whereas the differences in these LAI profiles were more pronounced in Ogée et al. (2003) (see Porté et al., 2000), and - although not 
explicitly given - probably in Bernier et al. (2001) as well. Both the photosynthetic capacity and the vertical LAI profile of different-aged needle classes, as well as the canopy LAI, are species- and stand-dependent. Therefore, the effects of omitting age-related photosynthetic capacity are very standspecific and the results for a single stand are hard to generalize. It should be noted that both Ogée et al. (2003) and Bernier et al. (2001) also accounted for an age-related difference in light interception efficiency resulting from changes in shoot structure, by including the ratio of shoot silhouette area to total needle area (STAR). The averaging of STAR over needle age might have contributed to the modelled canopy gas exchange differences in Ogée et al. (2003). For our Scots pine stand this was of less relevance, as the shoot structure of current-year and one-year-old needles was very similar.

The omittance of seasonal photosynthetic capacity variation, i.e. applying summer parameter values instead of full seasonal courses, did not lead to significant differences in simulated yearly GEP and $E_{\text {can }}$, relative to the reference scenario. Obviously, these differences depend on the magnitude of the seasonal variation. As canopy gas exchange rates are highest in summer, omitting seasonality could result in significant overestimations only when needle photosynthetic capacity is considerably lower in spring and autumn than in summer. Because this was not really the case at our temperate study site, it is only logical that differences were not significant in the present study. To the best of the authors' knowledge, the literature does not report other studies which calibrated a process-based model with direct leaf-level photosynthetic capacity measurements to quantify the effect of seasonal photosynthetic capacity variation on simulated coniferous canopy gas exchange. Yet, Santaren et al. (2007) indirectly showed the importance of including seasonal photosynthetic parameter variation in a study in which a processbased model was optimized to eddy covariance flux data for the abovementioned $P$. pinaster stand in France. The importance of including seasonal variation has also been shown for a mixed deciduous forest (Wilson et al., 2001).

\section{Conclusions}

From our results, we conclude that summer sampling of the different needle age classes suffices to provide photosynthetic parameter input for accurate simulations of yearly canopy gas exchange. In addition, we reckon caution is required when assessing relationships between photosynthetic parameters and needle $\mathrm{N}$ content from measurements on different needle age classes. These conclusions are valid, at least, for the Scots pine stand under study. Through its sparse canopy and its high nitrogen deposition load, this stand is not fully representative for temperate Scots pine stands in general. Hence, both the experimental and model findings of this study should not be generalized without caution. Furthermore, we conclude that well-parameterized process-based canopy models - as applied in this study - are a useful tool to quantify losses of predictive accuracy involved with canopy simplification. As they provide a fast means to estimate and rank sources of canopy gas exchange variation, they might even be helpful in guiding experimental design.

\section{Appendix A}

\section{Canopy model description}

The process-based multi-layer canopy model applied in this study is a generic model and simulates gross ecosystem productivity (GEP) and canopy transpiration $\left(E_{\text {can }}\right)$ on a halfhourly time resolution. It is driven by half-hourly input of incoming solar radiation $(I)$, air temperature $(T)$, atmospheric vapour pressure deficit (VPD), air $\mathrm{CO}_{2}$ concentration $\left(C_{\mathrm{a}}\right)$, atmospheric pressure $\left(p_{\mathrm{a}}\right)$, and wind speed $(v)$, as well as by daily LAI input of current-year and one-year-old needles. The model includes a radiation submodel (Goudriaan, 1977) and a leaf physiological submodel which combines the biochemical photosynthesis model of Farquhar (Farquhar et al., 1980) with a Ball-Berry-Leuning type stomatal model (Leuning, 1995). The canopy is treated as a horizontally multilayered structure with a canopy layer depth of $1 \mathrm{~m}$.

\section{A1 The radiation submodel}

At each time step, the radiation submodel splits up incoming irradiance at the canopy top $(I)$ into direct beam irradiance $\left(I_{\mathrm{b} 0}\right)$ and diffuse irradiance $\left(I_{\mathrm{d} 0}\right)$. The sunlit LAI fraction of each layer $i$ is calculated with Beer's law:

$f_{\mathrm{sun}(i)}=\exp \left(-k_{\mathrm{b}} \Omega \mathrm{LAI}_{\mathrm{c}(i)}\right)$

Here, $k_{\mathrm{b}}$ is the beam radiation extinction coefficient, $\Omega$ is a factor accounting for inter- and intra-crown foliage clumping (Nilson, 1971; Sinclair and Knoerr, 1982), and $\mathrm{LAI}_{\mathrm{c}(i)}$ is the cumulative LAI above a canopy layer $i$ from the canopy top. For a spherical needle angle distribution - which we assume in this study $-k_{\mathrm{b}}$ is given by:

$k_{\mathrm{b}}=0.5 / \sin \beta$

Here, $\beta$ is solar elevation angle, which is calculated from day of the year, time of day, and latitude (Campbell and Norman, 1998). The shaded LAI fraction of each canopy layer $i$ $\left(f_{\text {shad }(i)}\right)$ is given by:

$f_{\operatorname{shad}(i)}=1-f_{\operatorname{sun}(i)}$

Beam radiation intensity does not decline with canopy depth. Diffuse irradiance declines with canopy depth and is calculated for every layer $i$ with Beer's law:

$I_{\mathrm{d}(i)}=I_{\mathrm{d} 0} \exp \left(k_{\mathrm{d}} \mathrm{LAI}_{\mathrm{c}(i)}\right)$

Here, $k_{\mathrm{d}}$ is the diffuse radiation extinction coefficient. The total received irradiance by a sunlit fraction $\left(I_{\operatorname{sun}(i)}\right)$ is the 
sum of beam irradiance and diffuse irradiance. Shaded leaves only receive diffuse radiation:

$$
\begin{aligned}
& I_{\mathrm{sun}(i)}=\cos (\Pi / 3) I_{\mathrm{b} 0}+I_{\mathrm{d}(i)} \\
& I_{\mathrm{shad}(i)}=I_{\mathrm{d}(i)}
\end{aligned}
$$

Here, $\Pi / 3$ is the averaged leaf angle for a uniform needle angle distribution. Total received irradiance is converted to total received PAR. From total received PAR, the leaf physiological submodel simulates leaf-level photosynthesis and transpiration for current-year and one-year-old needles in each canopy layer fraction.

\section{A2 The leaf physiological submodel}

The leaf physiological submodel combines the biochemical photosynthesis model of Farquhar (Farquhar et al., 1980) with a Ball-Berry-Leuning type stomatal model (Leuning, 1995). The biochemical photosynthesis model of Farquhar simulates gross photosynthesis under both nitrogen limiting conditions $\left(A_{\mathrm{v}}\right)$ and light limiting conditions $\left(A_{\mathrm{j}}\right)$. Actual gross photosynthesis $\left(A_{\mathrm{b}}\right)$ is taken as the minimum of $A_{\mathrm{v}}$ and $A_{\mathrm{j}}$. Net photosynthesis $\left(A_{\mathrm{n}}\right)$ is calculated from $A_{\mathrm{b}}$ and leaf respiration rate $R_{\mathrm{d}}$ :

$A_{\mathrm{b}}=\min \left(A_{\mathrm{v}}, A_{\mathrm{j}}\right)$

$A_{\mathrm{n}}=A_{\mathrm{b}}-R_{\mathrm{d}}$

Nitrogen-limited gross photosynthesis is calculated by:

$A_{\mathrm{v}}=V_{\mathrm{m}} \frac{C_{\mathrm{i}}-\Gamma^{\prime}}{C_{\mathrm{i}}+K_{\mathrm{c}}\left(O / K_{\mathrm{o}}\right)}$

where $V_{\mathrm{m}}$ is the maximum carboxylation rate per unit leaf area under RuBP saturation, $\Gamma^{\prime}$ is the $\mathrm{CO}_{2}$ compensation point in the absence of mitochondrial respiration, $O$ is the intercellular $\mathrm{O}_{2}$ concentration, and $K_{\mathrm{c}}$ and $K_{\mathrm{o}}$ are the Michaelis-Menten constants of Rubisco for $\mathrm{CO}_{2}$ and $\mathrm{O}_{2}$, respectively. Gross photosynthesis in the case of lightlimitation is calculated by:

$A_{\mathrm{j}}=J \frac{C_{\mathrm{i}}-\Gamma^{\prime}}{4\left(C_{\mathrm{i}}+2 \Gamma^{\prime}\right)}$,

where $J$ is the electron transport rate at a given PAR. The electron transport rate at a given PAR $(J)$ is obtained from the maximum electron transport rate $\left(J_{\mathrm{m}}\right)$ by solving the quadratic equation:

$\theta J^{2}-\left(\mathrm{PAR}_{\mathrm{PSII}}+J_{\mathrm{m}}\right) J+\left(\operatorname{PAR}_{\mathrm{PSII}} J_{\mathrm{m}}\right)=0$

where $\theta$ is a curvature parameter and $\mathrm{PAR}_{\mathrm{PSII}}$ is the fraction of PAR effectively absorbed by photosystem II. In this study, PAR PSII is calculated from total received PAR at the leaf surface with:

$\operatorname{PAR}_{\mathrm{PSII}}=\alpha_{\mathrm{PAR}}\left(\frac{1-f}{2}\right) \mathrm{PAR}$ where $\alpha_{\mathrm{PAR}}$ is the needle PAR absorptivity and $f$ is a spectral correction factor.

The parameters $V_{\mathrm{m}}, R_{\mathrm{d}}, \Gamma^{\prime}, K_{\mathrm{c}}$, and $K_{\mathrm{o}}$ are temperaturedependent and calculated from reference values at $25^{\circ} \mathrm{C}$, applying an Arrhenius equation:

$x=x_{25} \exp \left(\frac{E_{\mathrm{a}}(T-25)}{298 R(T+273)}\right)$

Here $x$ is the parameter value, $x_{25}$ is the parameter value at $25^{\circ} \mathrm{C}, E_{\mathrm{a}}$ is the activation energy, $T$ is the temperature, and $R$ is the universal gas constant. For $J_{\mathrm{m}}$, this equation is extended to:

$x=$

$x_{25} \exp \left(\frac{E_{\mathrm{a}}(T-25)}{298 R(T+273)}\right) \frac{\left(1+\exp \left(\frac{298 S-H}{298 R}\right)\right)}{\left(1+\exp \left(\frac{(T+273) S-H}{(T+273) R}\right)\right)}$

where $H$ is a curvature parameter and $S$ is an electrontransport temperature response parameter. Parameter values at $25^{\circ} \mathrm{C}$ with their activation energies are listed in Table 2. The leaf respiration rate at $25^{\circ} \mathrm{C}\left(R_{\mathrm{d} 25}\right)$ scales with $V_{\mathrm{m} 25}$, according to a $R_{\mathrm{d} 25} / V_{\mathrm{m} 25}$ ratio.

\section{A3 The Ball-Berry-Leuning type stomatal model}

Stomatal conductance to $\mathrm{CO}_{2}\left(g_{\text {st }}\right)$ is calculated with a BallBerry-Leuning type model (Leuning, 1995):

$g_{\mathrm{st}}=g_{0}+a_{1} \frac{A_{\mathrm{b}}}{\left(C_{\mathrm{s}}-\Gamma\right)} f_{\mathrm{VPD}}$

Here, $g_{0}$ is night-time stomatal conductance, $a_{1}$ is an empirical scaling parameter, $C_{\mathrm{s}}$ is the leaf surface $\mathrm{CO}_{2}$ concentration, $\Gamma$ is the $\mathrm{CO}_{2}$ compensation point, and $f_{\mathrm{VPD}}$ is an empirical VPD-function, ranging between 0 and 1 . In this study, we apply a hyperbolic VPD-function:

$f_{\mathrm{VPD}}=\left(\mathrm{VPD} / \mathrm{VPD}_{0}\right)^{-1}$

where $\mathrm{VPD}_{0}$ is an empirical parameter. The supply formula is introduced to calculate $C_{\mathrm{s}}$ and to link the photosynthesis model with the stomatal conductance model:

$A_{\mathrm{n}}=g_{\mathrm{st}}\left(C_{\mathrm{s}}-C_{\mathrm{i}}\right)$

$A_{\mathrm{n}}=g_{\mathrm{bl}}\left(C_{\mathrm{a}}-C_{\mathrm{s}}\right)$

Here, $C_{\mathrm{a}}$ is the atmospheric $\mathrm{CO}_{2}$ concentration and $g_{\mathrm{bl}}$ is the leaf boundary layer conductance to $\mathrm{CO}_{2}$. The latter is calculated from wind speed $(v)$ and the characteristic needle dimension ( $d$; needle diameter) (Jones, 1992):

$g_{\mathrm{bl}}=0.14 \frac{v^{0.6}}{d^{0.4}}$

The system of equations is solved to obtain a steady-state solution for $A_{\mathrm{b}}$ and $g_{\mathrm{st}}$. Needle transpiration rate $(E)$ is then calculated by:

$E=1.56 g_{\text {tot }}\left(\mathrm{VPD} / p_{\mathrm{a}}\right)$ 
where $g_{\text {tot }}$ is total leaf conductance and $p_{\mathrm{a}}$ is atmospheric pressure. Total leaf conductance is obtained by summing $g_{\text {st }}$ and $g_{\mathrm{bl}}$, following the rules of adding conductance. The factor 1.56 converts conductance to $\mathrm{CO}_{2}$ to conductance to $\mathrm{H}_{2} \mathrm{O}$.

Calculated gross photosynthesis values for $j$-aged needles in the sunlit and shaded fractions of canopy layers $i$ ( $\left.A_{\text {bsun }(i, j)}, A_{\text {bshad }(i, j)}\right)$ are multiplied with the respective LAI values $\left(\mathrm{LAI}_{\operatorname{sun}(i, j)}, \mathrm{LAI}_{\text {shad }(i, j)}\right)$ and summed to obtain instant gross ecosystem productivity (GEP). Similarly, calculated transpiration for $j$-aged needles in the sunlit and shaded fractions of canopy layers $i\left(E_{\operatorname{sun}(i, j)}, E_{\operatorname{shad}(i, j)}\right)$ are integrated to obtain instant $E_{\text {can }}$ :

$$
\begin{aligned}
& \mathrm{GEP}= \\
& \sum_{i=1}^{n} \sum_{j=0}^{1}\left(A_{\mathrm{bsun}(i, j)} \mathrm{LAI}_{\mathrm{sun}(i, j)}+A_{\mathrm{bshad}(i, j)} \mathrm{LAI}_{\operatorname{shad}(i, j)}\right) \\
& E_{\mathrm{can}}= \\
& \sum_{i=1}^{n} \sum_{j=0}^{1}\left(E_{\operatorname{sun}(i, j)} \mathrm{LAI}_{\operatorname{sun}(i, j)}+E_{\operatorname{shad}(i, j)} \mathrm{LAI}_{\operatorname{shad}(i, j)}\right)
\end{aligned}
$$

Instant GEP and $E_{\text {can }}$ are then integrated over time to obtain daily and yearly GEP and $E_{\text {can }}$.

Acknowledgements. This research was in part supported by the CarboEurope IP (Sixth Framework Programme of the European Commission, Directorate-General Research, Priority 1.1.6.3 Global Change and Ecosystem, Contract No. GOCE-CT-2003-505572). We gratefully acknowledge Daniele Bocardelli for destructive needle biomass measurements. We thank Nadine Calluy and Kristine Crous for needle $\mathrm{N}$ analysis. We are grateful to the Flemish Research Institute for Nature and Forestry (INBO) for provision of site meteorological and litter fall data. We also thank Freja Dreesen and Kim Naudts for help with statistical analyses. Finally, we thank two anonymous reviewers for their constructive comments and Matthew Letts for his short comment on an earlier version of this the manuscript.

Edited by: E. Falge

\section{References}

Aubinet, M., Grelle, A., Ibrom, A., Rannik, U., Moncrieff, J., Foken, T., Kowalski, A. S., Martin, P. H., Berbigier, P., Bernhofer, C., Clement, R., Elbers, J., Granier, A., Grunwald, T., Morgenstern, K., Pilegaard, K., Rebmann, C., Snijders, W., Valentini, R., and Vesala, T.: Estimates of the annual net carbon and water exchange of forests: The EUROFLUX methodology, in: Advances in Ecological Research, Vol 30, Academic Press Inc, San Diego, USA, 113-175, 2000.

Baeyens, L., Van Slycken, J., and Stevens, D.: Description of the soil profile in Brasschaat, Internal Research Paper, Institute for Forestry and Game Management, Geraardsbergen, Belgium, 1993.

Baldocchi, D. and Meyers, T.: On using eco-physiological, micrometeorological and biogeochemical theory to evaluate carbon dioxide, water vapor and trace gas fluxes over vegetation: a perspective, Agr. Forest Meteorol., 90, 1-25, 1998.

Bernier, P. Y., Raulier, F., Stenberg, P., and Ung, C.-H.: Importance of needle age and shoot structure on canopy net photosynthesis of balsam fir (Abies balsamea): a spatially inexplicit modeling analysis, Tree Physiol., 21, 815-830, 2001.

Bråkenhielm, S. and Qinghong, L.: Spatial and temporal variability of algal and lichen epiphytes on trees in relation to pollutant deposition in Sweden, Water Air Soil Poll., 100, 119-132, 1995.

Campbell, G. S. and Norman, J. M. (eds.): An Introduction to Environmental Biophysics., second edition, Springer-Verlag, New York, United States, 289 pp., 1998.

Carrara, A., Kowalski, A. S., Neirynck, J., Janssens, I. A., Yuste, J. C., and Ceulemans, R.: Net ecosystem $\mathrm{CO}_{2}$ exchange of mixed forest in Belgium over 5 years, Agr. Forest Meteorol., 119, 209227, 2003.

Čermák, J., Riguzzi, F., and Ceulemans, R.: Scaling up from the individual tree to the stand level in Scots pine. I. Needle distribution, overall crown and root geometry, Ann. For. Sci., 55, 63-88, 1998.

de Pury, D. G. G. and Farquhar, G. D.: Simple scaling of photosynthesis from leaves to canopies without the errors of big-leaf models, Plant Cell Environ., 20, 537-557, 1997.

Ellsworth, D. S.: Seasonal $\mathrm{CO}_{2}$ assimilation and stomatal limitations in a Pinus taeda canopy, Tree Physiol., 20, 435-445, 2000.

Evans, J. R.: Photosynthesis and nitrogen relationships in leaves of $\mathrm{C}_{3}$ plants, Oecologia, 78, 9-19, 1989.

Farquhar, G. D, von Caemerrer, S., and Berry, J. A.: A biochemical model of photosynthetic $\mathrm{CO}_{2}$ assimilation in leaves of $\mathrm{C}_{3}$ species, Planta, 149, 78-90, 1980.

Field, C.: Allocating leaf nitrogen for the maximization of carbon gain: leaf age as control for the allocation program, Oecologia, 56, 341-347, 1983.

Field, C. and Mooney, H. A.: The photosynthesis-nitrogen relationship in wild plants, in: On the Economy of Plant Form and Function, Givnish, T. J. (Ed.), Cambridge University Press, Cambridge, United Kingdom, 25-55, 1986.

Gielen, B., Jach, M. E., and Ceulemans, R.: Effects of season, needle age, and elevated atmospheric $\mathrm{CO}_{2}$ on chlorophyll fluorescence parameters and needle nitrogen concentration in Scots pine (Pinus sylvestris), Photosynthetica, 38, 13-21, 2000.

Göransson, A.: Grönalger på granbarr - Mängder ackumulerade näringsämnen och metaller. SLU, Skogsmästerskolan, Rapport/examenarbete, 29, 1-21, 1992 (in Swedish with English abstract).

Goudriaan, J.: Crop micrometeorology: a Simulation Study, Pudoc, Center for Agricultural Publishing and Documentation, Wageningen, The Netherlands, 249 pp., 1977.

Han, Q., Kawasaki, T., Nakano, T., and Chiba, Y.: Leaf age effects on seasonal variability in photosynthetic parameters and its relationships with leaf mass per area and leaf nitrogen concentration within a Pinus densiflora crown, Tree Physiol., 28, 551-558, 2008.

Helmisaari, H. S.: Temporal variation in nutrient concentrations of Pinus sylvestris needles, Scand. J. Forest Res., 5, 177-193, 1990.

Jach, M. E. and Ceulemans, R.: Effects of season, needle age, and elevated atmospheric $\mathrm{CO}_{2}$ on photosynthesis in Scots pine ( $\mathrm{Pi}$ nus sylvestris), Tree Physiol., 20, 145-157, 2000.

Janssens, I. A., Sampson, D. A., Čermák, J., Meiresonne, L., 
Riguzzi, F., Overloop, S., and Ceulemans, R.: Above- and below-ground phytomass and carbon storage in a Belgian Scots pine stand, Ann. For. Sci., 56, 81-90, 1999.

Janssens, I. A., Schauvliege, M., Samson, R., Lust, N., and Ceulemans, R.: Studie van de koolstofbalans van en de koolstofopslag in het Vlaamse bos, Eindverslag aan het Ministerie van de Vlaamse Gemeenschap, Administratie AMINAL, Afdeling Bos en Groen, 1998 (in Dutch).

Jonckheere, I., Muys, B., and Coppin, P.: Allometry and evaluation of in situ optical LAI determination in Scots pine: a case study in Belgium, Tree Physiol., 25, 723-732, 2005a.

Jonckheere, I., Muys, B., and Coppin, P.: Assessment of automatic gap fraction estimation of forests from digital hemispherical photography, Agr. For. Meteorol., 132, 96-114, 2005b.

Jonckheere, I., Nackaerts, K., van Aardt, J., Muys, B., and Coppin, P.: The relevance of fractal dimension for foliage distribution quantification in forest canopies: a model approach, Ecol. Modell., 197, 179-195, 2006.

Jones, H. G.: Plants and Microclimate, A quantitative approach to environmental plant physiology, second edition, University Press, Cambridge, United Kingdom., 428 pp., 1992.

Kattge, J., Knorr, W., Raddatz, T., and Wirth, C.: Quantifying photosynthetic capacity and nitrogen use efficiency for earth system models, Glob. Change Biol., 15, 976-991, 2009.

Kellomäki, S. and Wang, K.-Y.: Photosynthetic responses of Scots pine to elevated $\mathrm{CO}_{2}$ and nitrogen supply: results of a branch-inbag experiment, Tree Physiol., 17, 231-240, 1997.

Kowalczyk, E. A., Wang, Y. P., Law, R. M., Davies, H. L., McGregor, J. L., and Abramowitz, G.: The CSIRO Atmosphere Biosphere Land Exchange (CABLE) model for use in climate models and as an offline model, CSIRO Marine and Atmospheric Research paper 013, 2006.

Kowalski, A. S., Overloop, S., and Ceulemans, R.: Eddy fluxes above a Belgian, Campine forest and their relationship with predicting variables, in: Forest Ecosystem Modelling, Upscaling and Remote Sensing, edited by: Ceulemans, R., Veroustraete, F., Gond, V., and Van Rensbergen, J., SPB Academic Publishing, The Hague, The Netherlands, 3-17, 2000.

Lasslop, G., Reichstein, M., Papale, D., Richardson, A. D., Arneth, A., Barr, A., Stoy, P., and Wohlfahrt, G.: Separation of net ecosystem exchange into assimilation and respiration using a light response curve approach: critical issues and global evaluation, Glob. Change Biol., 16, 187-208, 2010.

Letts, M. G., Nakonechny, K. N., Van Gaalen, E. K., and Smith, C. M.: Physiological acclimation of Pinus flexilis to drought stress on contrasting slope aspects in Waterton Lakes National Park, Alberta, Canada, Can. J. Forest Res., 39, 629-641, 2009.

Leuning, R.: A critical appraisal of a combined stomatalphotosynthesis model for $\mathrm{C}_{3}$ plants, Plant Cell Environ., 18, 339-355, 1995.

Luyssaert, S., Inglima, I., Jung, M., Richardson, A. D., Reichstein, M., Papale, D., Piao, S. L., Schulze, E.-D., Wingate, L., Matteucci, G., Aragao, L., Aubinet, M., Beer, C., Bernhofer, C., Black, K. G., Bonal, D., Bonnefond, J. -M., Chambers, J., Ciais, P., Cook, B., Davis, K.J., Dolman, A. J., Gielen, B., Goulden, M., Grace, J., Granier, A., Grelle, A., Griffis, T., Grünwald, T., Guidolotti, G., Hanson, P. J., Harding, R., Holinger, D. Y., Hutyra, L. R., Kolari, P., Kruijt, B., Kutsch, W., Lagergren, F., Laurila, T., Law, B. E., Le Maire, G., Lindroth, A., Loustau,
D., Malhi, Y., Mateus, J., Migliavacca, M., Misson, L., Montagnani, L., Moncrieff, J., Moors, E., Munger, J. W., Nikinmaa, E., Ollinger, S. V., Pita, G., Rebmann, C., Roupsard, O., Saigusa, N., Sanz, J. M., Seufert, G., Sierra, C., Smith, M.-L., Tang, J., Valentini, R., Vesala, T., and Janssens, I. A.: $\mathrm{CO}_{2}$ balance of boreal, temperate, and tropical forests derived from a global database, Glob. Change Biol., 13, 2509-2537, 2007.

Medlyn, B. E., Dreyer, E., Ellsworth, D., Forstreuter, M., Harley, P. C., Kirchbaum, M. U. F., Le Roux, X., Montpied, P., Strassemeyer, J., Walcroft, A., Wang, K., and Loustau, D.: Temperature response of parameters of a biochemically based model of photosynthesis, II. A review of experimental data, Plant Cell Environ., 25, 1167-1179, 2002.

Misson, L., Tu, K. P., Boniello, R. A., and Goldstein, A. H.: Seasonality of photosynthetic parameters in a multi-specific and vertically complex forest ecosystem in the Sierra Nevada of California, Tree Physiol., 26, 729-741, 2006.

Mohren, G. M. J. and van de Veen, J. R.: Forest growth in relation to site conditions: Application of the model FORGRO to the Solling spruce site, Ecol. Modell., 83, 173-183, 1995.

Monteith, J. L. (ed.): Vegetation and the atmosphere, Volume I, Principles, Academic Press, London, United Kingdom, 298 pp., 1975.

Näsholm, T. and Ericsson, A.: Seasonal changes in amino acids, protein and total nitrogen in needles of fertilized Scots pine trees, Tree Physiol., 6, 267-281, 1990.

Neirynck, J., Janssens, I. A., Roskams, P., Quataert, P., Verschelde, P., and Ceulemans, R.: Nitrogen biogeochemistry of a mature Scots pine forest subjected to high nitrogen loads, Biogeochemistry, 91, 201-222, 2008.

Neirynck, J., Kowalski, A. S., Carrara, A., and Ceulemans, R.: Driving forces for ammonia fluxes over mixed forest subjected to high deposition loads, Atmos. Environ., 39, 5013-5024, 2005.

Neirynck, J., Kowalski, A. S., Carrara, A., Genouw, G., Berghmans, P., and Ceulemans, R.: Fluxes of oxidised and reduced nitrogen above a mixed coniferous forest exposed to various nitrogen emission sources, Environ. Pollut., 149, 31-43, 2007.

Niinemets, Ü.: Stomatal conductance alone does not explain the decline in foliar photosynthetic rates with increasing tree age and size in Picea abies and Pinus sylvestris, Tree Physiol., 22, 515535, 2002.

Niinemets, Ü., Díaz-Espejo, A., Flexas, J., Galmés, J., and Warren, C. R.: Role of mesophyll diffusion conductance in constraining potential photosynthetic productivity in the field, J. Exp. Bot., 60, 2249-2270, 2009.

Niinemets, Ü., Ellsworth, D., Lukjanova, A., and Tobias, M.: Site fertility and the morphological and photosynthetic acclimation of Pinus sylvestris needles to light, Tree Physiol., 21, 1231-1244, 2001.

Nilson, T.: A theoretical analysis of frequency gaps in plant stands, Agr. Meteorol., 8, 25-38, 1971.

Ogeé, J., Brunet, Y., Loustau, D., Berbigier, P., and Delzon, S.: MuSICA, a $\mathrm{CO}_{2}$, water and energy multilayer, multileaf pine forest model: evaluation from hourly to yearly time scales and sensitivity analysis, Glob. Change Biol., 9, 697-717, 2003.

Papale, D., Reichstein, M., Aubinet, M., Canfora, E., Bernhofer, C., Kutsch, W., Longdoz, B., Rambal, S., Valentini, R., Vesala, T., and Yakir, D.: Towards a standardized processing of Net Ecosystem Exchange measured with eddy covariance technique: algo- 
rithms and uncertainty estimation, Biogeosciences, 3, 571-583, 2006, http://www.biogeosciences.net/3/571/2006/.

Peters, J., González-Rodríguez, Á. M., Jiménez, M. S., Morales, D., and Wieser, G.: Influence of canopy position, needle age and season on the foliar gas exchange of Pinus canariensis, Eur. J. For. Res., 127, 293-299, 2008.

Poikolainen, J., Lippo, H., Hongisto, M., Kubin, E., Mikkola, K., and Lindgren, M.: On the abundance of epiphytic green algae in relation to the nitrogen concentrations of biomonitors and nitrogen deposition in Finland, Environ. Pollut., 102, 85-92, 1998.

Porté, A., Bosc, A., Champion, I., and Loustau, D.: Estimating the foliage area of Maritime pine (Pinus pinaster Aït.) branches and crown with application to modelling the foliage area distribution in the crown, Ann. For. Sci., 57, 73-86, 2000.

Reichstein, M., Falge, E., Baldocchi, D., Papale, D., Aubinet, M., Berbigier, P., Bernhofer, C., Buchmann, N., Gilmanov, T., Granier, A., Grunwald, T., Havrankova, K., Ilvesniemi, H., Janous, D., Knohl, A., Laurila, T., Lohila, A., Loustau, D., Matteucci, G., Meyers, T., Miglietta, F., Ourcival, J. M., Pumpanen, J., Rambal, S., Rotenberg, E., Sanz, M., Tenhunen, J., Seufert, G., Vaccari, F., Vesala, T., Yakir, D., and Valentini, R.: On the separation of net ecosystem exchange into assimilation and ecosystem respiration: review and improved algorithm, Glob. Change Biol., 11, 1424-1439, 2005.

Roskams, P. and Neirynck, J.: De voedingstoestand van grove den (Pinus sylvestris L.) in het level II-proefvlak in Brasschaat, Mededelingen van het Instituut voor Bosbouw en Wildbeheer, Institute for Forestry and Game Management, 1, 23-45, 1999 (in Dutch).

Roskams, P., Sioen, G., and Overloop, S.: Meetnet voor de intensieve monitoring van het bosecosysteem in het Vlaamse Gewest - Resultaten 1991-1992, Institute for Forestry and Game Management, Ministry of the Flemish Community, 191 pp., 1997 (in Dutch).

Rundel, P. W. and Yoder, B. J.: Ecophysiology of Pinus, in: Ecology and Biogeography of Pinus, edited by: Richardson, D. M., Cambridge University Press, United Kingdom, 296-322, 2000.

Santaren, D., Peylin, P., Viovy, N., and Ciais, P.: Optimizing a process-based ecosystem model with eddy-covariance flux measurements: A pine forest in southern France, Global Biogeochem. Cy., 21, GB2013, doi:10.1029/2006GB002834, 2007.

Sinclair, T. R. and Knoerr, K. R.: Distribution of photosynthetically active radiation in the canopy of a loblolly pine plantation, $\mathrm{J}$. Appl. Ecol., 19, 183-191, 1982.

Søchting, U.: Epiphyllic cover on spruce needles in Denmark, Ann. Bot. Fenn., 34, 157-164, 1997.
Stenberg, P., Kuuluvainen, T., Kellomäki, S., Grace, J. C., Jokela, E. H., and Gholz, H. L.: Crown structure, light interception, and productivity of pine trees and stands, Ecol. Bull., 43, 20-34, 1994.

Tingey, D. T., Laurence, J. A., Weber, J. A., Greene, J., Hogsett, W. E., Brown, S., and Lee, E. H.: Elevated $\mathrm{CO}_{2}$ and temperature alter the response of Pinus ponderosa to ozone: A simulation analysis, Ecol. Appl., 11, 1412-1424, 2001.

Van den Berge, K., Maddelein, D., De Vos, B., and Roskams, P.: Analyse van de Luchtverontreiniging en de gevolgen daarvan op het bosecosysteem, Study Report no. 19 of Aminal, Ministry of the Flemish Community, 1992 (in Dutch).

Vapaavuori, E. M., Vuorinen, A. H., Aphalo, P. J., and Smolander, H.: Relationship between net photosynthesis and nitrogen in Scots pine: Seasonal variation in seedlings and shoots, Plant Soil, 168-169, 263-270, 1995.

Verseghy, D. L.:, The Canadian Land Surface Scheme (CLASS): Its history and future, Atmos. Ocean, 38, 15-35, 2000.

Wang, K., Kellomäki, S., and Laitinen, K.: Effects of needle age, long-term temperature, and $\mathrm{CO}_{2}$ treatments on the photosynthesis of Scots pine, Tree Physiol., 15, 211-218, 1995.

Wang, Y.-P. and Leuning, R.: A two-leaf model for canopy conductance, photosynthesis and portioning of available energy I: Model description and comparison with a multi-layered model, Agr. Forest Meteorol., 91, 89-111, 1998.

Warren, C. R.: Why does photosynthesis decrease with needle age in Pinus pinaster?, Trees, 20, 157-164, 2006.

Warren, C. R., Dreyer, E., and Adams, M. A.: PhotosynthesisRubisco relationships on foliage of Pinus sylvestris in response to nitrogen supply and the proposed role of Rubisco and amino acids as nitrogen stores, Trees, 17, 359-366, 2003.

Weiskittel, A. R.: Development of a Hybrid Modeling Framework for Intensively Managed Douglas-Fir Plantations in the Pacific Northwest, Ph.D., Oregon State University, Corvallis, Oregon, United States, 311 pp., 2006.

Willmott, C. J.: On the validation of models, Phys Geogr., 2, 184194, 1981.

Wilson, K. B., Baldocchi, D. D., and Hanson, P. J.: Leaf age affects the seasonal pattern of photosynthetic capacity and net ecosystem exchange of carbon in a deciduous forest, Plant Cell Environ., 24, 571-583, 2001.

Xiao, C.-W., Curiel Yuste, J., Janssens, I. A., Roskams, P., Nachtegale, L., Carrara, A., Sanchez, B. Y., and Ceulemans, R.: Aboveand belowground biomass and net primary production in a 73year-old Scots pine forest, Tree Physiol., 23, 505-516, 2003.

Xiao, C.-W., Janssens, I. A., Curiel Yuste, J., and Ceulemans, R.: Variation of specific leaf area index in mature Scots pine, TreesStruc. Func., 20, 304-310, 2006. 